\title{
Mineralogy, distribution, occurrence and removability of trace elements during the coal preparation of No. 6 coal from Heidaigou mine
}

\author{
Xiangfei Bai · Yue Wang • Wenhua Li
}

Received: 24 November 2014/Revised: 15 December 2014/Accepted: 16 December 2014/Published online: 10 March 2015

(C) The Author(s) 2015. This article is published with open access at Springerlink.com

\begin{abstract}
Optical microscopy and scanning electron microscopy in conjunction with energy dispersed X-ray spectrometry (SEM-EDX) were used to study the minerals and the concentrations of 33 trace elements in No. 6 coal from Heidaigou mine. The distributions, organic affinity and removability of 18 trace elements were studied by float-sink experiments. A determination of the maceral groups was also undertaken. A high mineral content, dominated by kaolinite, was found in No. 6 coal from Heidaigou mine. The bauxite content was relatively high and it was mainly present as individual particles in fusinite lumens or was intimately intergrown with carbonate minerals. The pyrite and quartz contents were low. Some marcasite with a parallel twin structure was observed by cross-polar reflected light. A small amount of bean-like goyazite was present in the calcite. The weighted trace element content in Heidaigou formations is relatively low, which is beneficial for coal processing and utilization. The concentrations of $\mathrm{Ga}, \mathrm{Hg}, \mathrm{Pb}$, Se, Th, Ta are relatively high compared with the average values of Chinese coals. As, $\mathrm{Hg}$, Mo, Ge, Ga, Ta, Ti, W, Mn are mainly present in minerals while B, Be, Th, P, Sc, Sr, V, Y, Yb are mainly found in organic matter. As, Ge, Hg, Mo are mainly present in sulfides and $\mathrm{Be}, \mathrm{Th}, \mathrm{P}, \mathrm{Sc}, \mathrm{Sr}, \mathrm{Y}, \mathrm{Yb}$ are mainly present in inertinite. B and V are mainly present in vitrinite. The high organic affinity and the low theoretical removability of most trace elements cause difficulties in removing them during coal preparation.
\end{abstract}

Keywords Trace elements · Occurrence · Organic affinity · Removability · Heidaigou coal

\section{Introduction}

The Heidaigou coal mine is located in the middle of the Junger coalfield in the Inner Mongolia Autonomous Region. More than 30 million tons of raw coal is produced every year. As a preferred feedstock for power plants Heidaigou coal is primarily used for the generation of

X. Bai $(\bowtie) \cdot$ Y. Wang

Beijing Research Institute of Coal Chemistry, China Coal

Research Institute, Beijing 100013, China

e-mail: bxf1970@sina.com

X. Bai · Y. Wang

State Key Laboratory of Coal Mining and Clean Utilization, Beijing 100013, China

W. Li

National Institute of Clean-and-Low-Carbon Energy,

Beijing 102209, China electricity. A low degree of anogenic metamorphism is the main coalification type. The main mineable coal bed, the No. 6 coal seam, was formed during the drying terrestrial delta deposition environment of the late Carboniferous period (Mao and Xu 1999).

Research into minimizing the hazards caused by trace elements is an important part of coal utilization technologies. Studies into the distribution and the occurrence of trace elements in coal are important. Bench samples from a drill core of the No. 6 coal seam were used to study the distributions and occurrence of trace elements in Heidaigou coal. It was found that $\mathrm{Ga}, \mathrm{Se}, \mathrm{Sr}, \mathrm{Zr}, \mathrm{Hg}, \mathrm{Pb}$, Th and REEs were relatively abundant while the Ga concentration was sufficient for industrial use. Ga, Th and REEs were found to be mainly distributed in boehmite in the No. 6 coal (Dai et al. 2006a). Their relative abundance in boehmite comes from the periodic drying of peat because of changes in the water table during the coal forming period (Dai et al. 
2007). It has been shown that high concentrations of Ga in weathered coal come from the absorption of humic acid (Wang et al. 2011). Lead and selenium are mainly present in galena, clausthalite, and selenio-galena while $\mathrm{Hg}$ is mainly found in clausthalite and sulfides. High concentrations of $\mathrm{Zr}$ are attributed to the presence of zircon and $\mathrm{Sr}$ is present in goyazite (Dai et al. 2006b, c; Li and Ren 2006). No. 6 coal from the Haerwusu surface mine that adjoins Heidaigou is enriched in $\mathrm{Li}, \mathrm{F}, \mathrm{Ga}, \mathrm{Se}, \mathrm{Sr}, \mathrm{Zr}$, REEs, $\mathrm{Pb}$, and $\mathrm{Th}$ while $\mathrm{Ga}$ and $\mathrm{F}$ were mainly found in the clay minerals and partially in organic matter. $\mathrm{Se}$ and $\mathrm{Pb}$ are mainly present in the epigenetic clausthalite that fills the fractures. Sr and P may share the same carriers (Dai et al. 2008).

As a low-cost and mature technology coal preparation effectively reduces the amount of harmful elements in addition to improving the calorific values and lowering the ash and sulfur content of coal (Martinez-Tarazona et al. 1992). Coal preparation is thus believed to be an effective method to lower the concentrations of trace elements. This reduces the amount of environmental pollution by the trace elements (Pires et al. 1997; Klika et al. 1997, 2000; Tang et al. 2005; Song et al. 2010).

The geological setting of Heidaigou mine has been reported (Dai et al. 2006c). Production samples were used to study the coal's mineral composition. The distributions, occurrence and removability of trace elements from No. 6 coal were determined using float-sink experiments, petrological and statistical methods in this study. Correlation analysis was conducted to study the relationship among the trace elements and between the trace elements and the maceral groups, the ash content and the sulfur content. The

Table 1 Results of the proximate and ultimate analyses (wt $\%$ )

\begin{tabular}{|c|c|c|c|c|c|c|c|c|}
\hline \multicolumn{4}{|c|}{ Proximate analysis } & \multicolumn{5}{|c|}{ Ultimate analysis } \\
\hline$M_{\mathrm{ad}}$ & $A_{\mathrm{d}}$ & $V_{\text {daf }}$ & $\mathrm{FC}_{\mathrm{d}}$ & $\mathrm{C}_{\mathrm{daf}}$ & $\mathrm{H}_{\text {daf }}$ & $\mathrm{N}_{\text {daf }}$ & $\mathrm{O}_{\text {daf }}$ & $\mathrm{S}_{\mathrm{daf}}$ \\
\hline 8.65 & 24.67 & 38.50 & 46.33 & 81.52 & 4.51 & 1.30 & 12.02 & 0.65 \\
\hline
\end{tabular}

Table 2 Total sulfur and forms of sulfur in the coal (wt $\%$ )

\begin{tabular}{llll}
\hline $\mathrm{S}_{\mathrm{t}, \mathrm{d}}$ & \multicolumn{3}{l}{ Forms of sulfur } \\
\cline { 2 - 4 } & $\mathrm{S}_{\mathrm{p}, \mathrm{d}}$ & $\mathrm{S}_{\mathrm{s}, \mathrm{d}}$ & $\mathrm{S}_{\mathrm{o}, \mathrm{d}}$ \\
\hline 0.49 & 0.33 & 0.00 & 0.16 \\
\hline
\end{tabular}

theoretical content of trace elements in the macerals and minerals were then calculated using linear equations and the organic affinities of the trace elements are discussed. The removabilities of the trace elements were determined to provide guidance for the clean and environmentallyfriendly use of Heidaigou coal.

\section{Experiments}

\subsection{Characteristics of the samples}

The samples were obtained from the No. 6 coal seam at the Heidaigou surface mine according to GB/T 481-1993 (production coal sampling method). Proximate analyses (GB/T 212-2008), ultimate analyses (GB/T 476-2008,GB/ $\mathrm{T}$ 19227-2008), total sulfur (GB/T 214-2007) and forms of sulfur (GB/T 215-2003), ash composition (GB/T 1574-2007), the fusibility of ash (GB/T 219-2008), the maceral groups (GB/T 8899-2008), the microlithotype composition (GB/T 15590-2008), and the mean maximum reflectance of the vitrinite (GB/T 6948-2008) were determined following Chinese standards and the results are listed in Tables 1, 2, 3, 4, 5 and 6.

Heidaigou coal is a low-rank bituminous coal with a high ash content. The sulfur content is low and dominated by pyritic sulfur. The $\mathrm{Al}_{2} \mathrm{O}_{3}$ content is high while $\mathrm{SiO}_{2}$ is relatively low in the ash. This results a high ash fusion temperature. The mine is located at the north edge of the carboniferous-permian coal accumulation basin in Northern China. The vitrinite content is lower than the average of the area while the inertinite and liptinite contents are higher

Table 4 Fusibility of the coal ash $\left({ }^{\circ} \mathrm{C}\right)$

\begin{tabular}{llll}
\hline DT & ST & HT & FT \\
\hline 1,380 & $>1,500$ & $>1,500$ & $>1,500$ \\
\hline
\end{tabular}

Table 5 Maceral groups and the mean maximum reflectance of vitrinite

\begin{tabular}{lllll}
\hline \multicolumn{2}{l}{ Maceral group (vol\%) } & & \multirow{2}{*}{$R_{\max }^{o}(\%)$} \\
\cline { 1 - 4 } Vitrinite & Inertinite & Liptinite & Mineral & \\
\hline 31.87 & 44.88 & 8.78 & 14.48 & 0.52 \\
\hline
\end{tabular}

Table 3 Ash composition analysis (wt \%)

\begin{tabular}{llllllllll}
\hline $\mathrm{SiO}_{2}$ & $\mathrm{Al}_{2} \mathrm{O}_{3}$ & $\mathrm{Fe}_{2} \mathrm{O}_{3}$ & $\mathrm{CaO}$ & $\mathrm{MgO}$ & $\mathrm{SO}_{3}$ & $\mathrm{TiO}_{2}$ & $\mathrm{P}_{2} \mathrm{O}_{5}$ & $\mathrm{Na}_{2} \mathrm{O}$ & $\mathrm{K}_{2} \mathrm{O}$ \\
\hline 23.84 & 57.18 & 3.58 & 5.12 & 0.43 & 0.72 & 2.48 & 0.18 & 0.24 & 0.81 \\
\hline
\end{tabular}


Table 6 Microlithotypes in Heidaigou coal (vol\%)

\begin{tabular}{|c|c|c|c|c|c|c|c|}
\hline Vitrite & Clarite & Inertrite & Vitrinertite & Trimacerite & Liptite & Durite & Minerite \\
\hline 11.33 & 4.30 & 17.38 & 12.11 & 13.48 & 0.00 & 29.88 & 11.52 \\
\hline
\end{tabular}

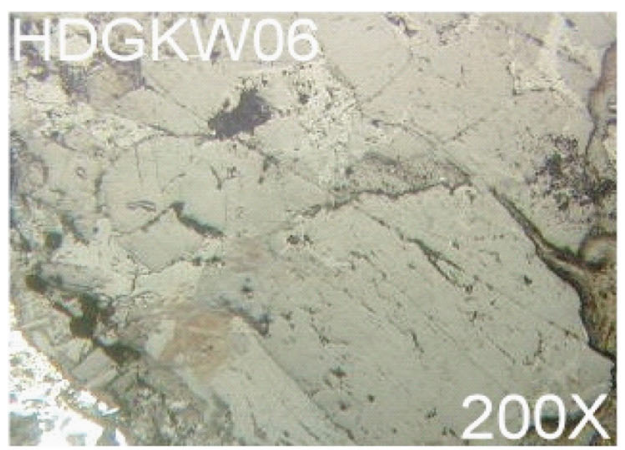

(a) Optical microscopy

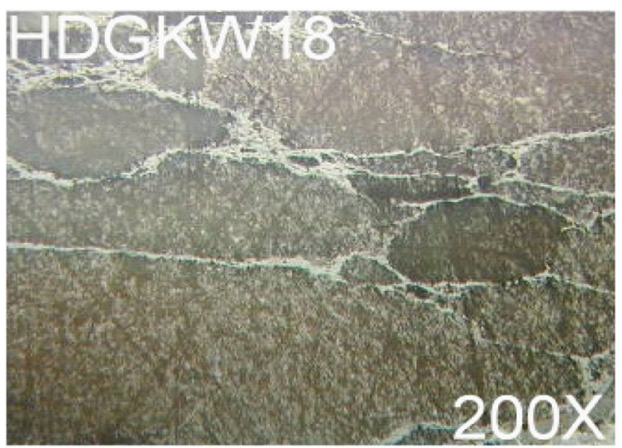

(c) Polarized light

Spectrum: HDG 01 Range: $20 \mathrm{keV}$

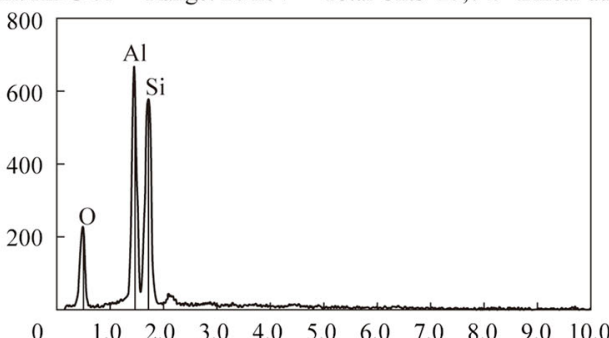

(e) X-ray energy spectrum diagram scanned area, $250 \mu \mathrm{m} \times 250 \mu \mathrm{m}$

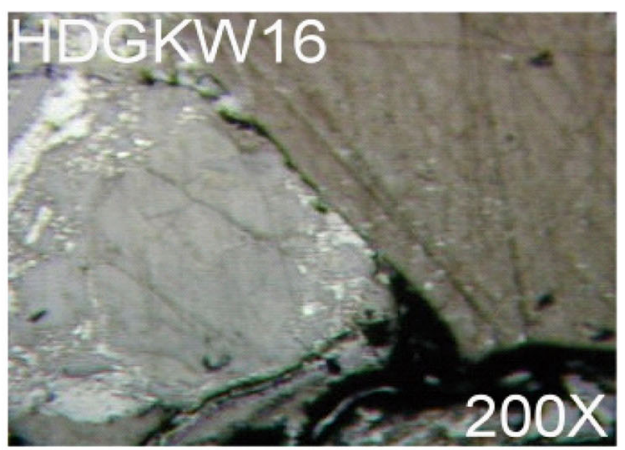

(b) Air

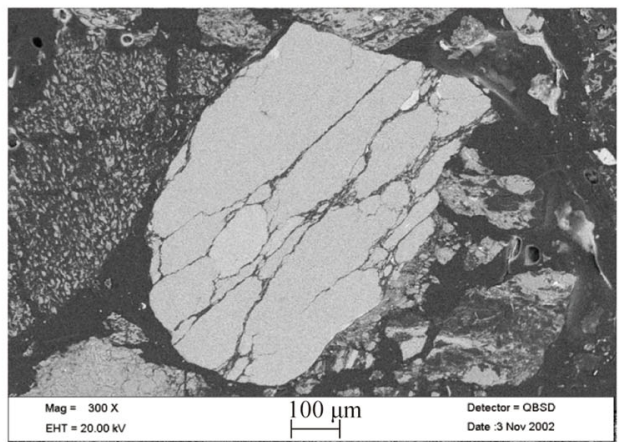

(d) SEM backscattered electron image

Total Cnts $=25,049$ Linear auto-VS $=660$

Fig. 1 Kaolinite in Heidaigou coal

(Han 1996). The dominant vitrinite macerals are telocollinite and desmocollinite. A small amount of telinite is also present. The liptinite group is mainly represented by sporinite, which disperses in the desmocollinite and in the matrix of the inertinite in the bedding direction. Fragmental fusinite usually mixes with semifusinite. The main microlithotypes are vitrite, trimacerite and durite while a small amount of clarite, inertrite and vitrinertite are present. Vitrite is usually uniform while trimacerite is fragmental or of lineation shape. Durite is composed of an inertinite matrix and a clastic texture.

\subsection{Mineral analysis}

Minerals are the main carriers of most trace elements in coal. The distributions, occurrence and removability of the 
Table $7 \mathrm{Si} / \mathrm{Al}$ ratio of the clay minerals

\begin{tabular}{llll}
\hline Sample No. & $\begin{array}{l}\text { Scanning area } \\
(\mu \mathrm{m} \times \mu \mathrm{m})\end{array}$ & $\begin{array}{l}\text { Acquisition } \\
\text { time }(\mathrm{s})\end{array}$ & Si/Al ratio \\
\hline 1 & $250 \times 250$ & 50 & 1.04 \\
2 & $250 \times 250$ & 50 & 1.06 \\
3 & $100 \times 80$ & 50 & 0.90 \\
4 & $250 \times 250$ & 50 & 1.01 \\
\hline
\end{tabular}
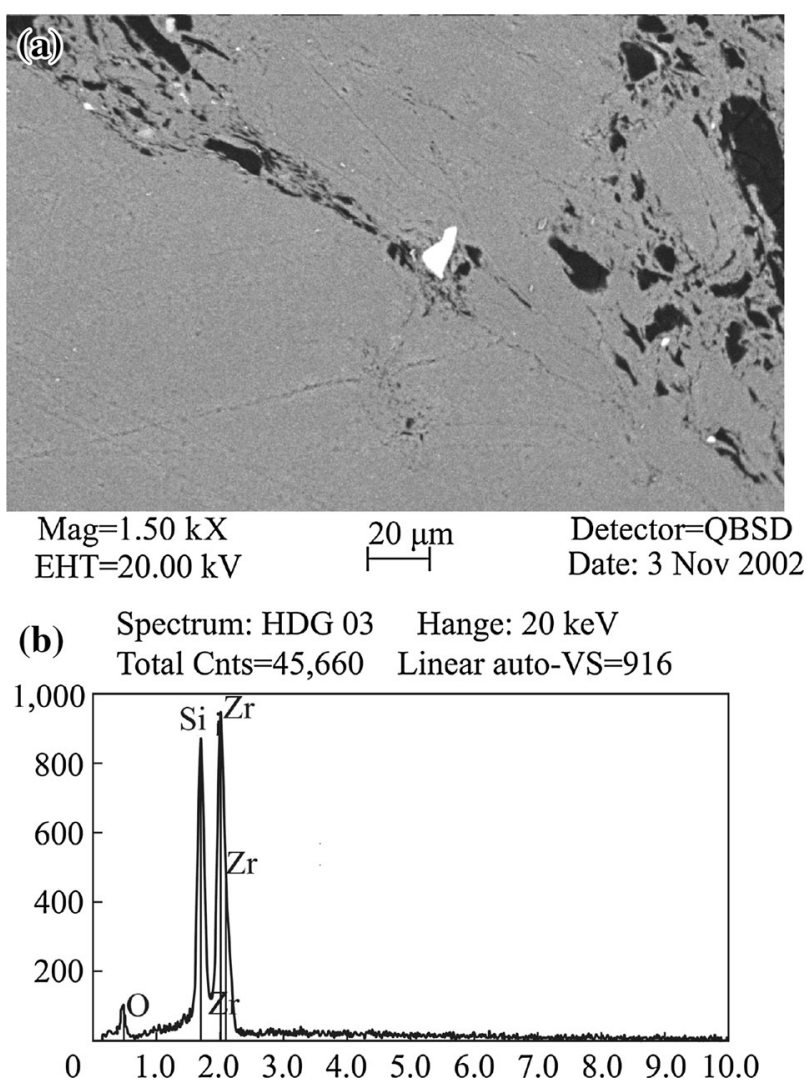

Fig. 2 Fine-grain zircon in the kaolinite

trace elements are largely affected by the presence of minerals. They are closely related to each other in terms of their genesis. Samples were prepared for microscopic analysis (ZEISS AXIOSKOP 40 optical microscope) according to the Chinese standard (GB/T 16773-2008). The optical characteristics of the minerals are described below and photographs were taken. A scanning electron microscope in conjunction with energy-dispersive X-ray spectrometry (SEM-EDS) was used to study the characteristics of the minerals and also to determine the distributions of elements in the macerals and in the minerals by spot and

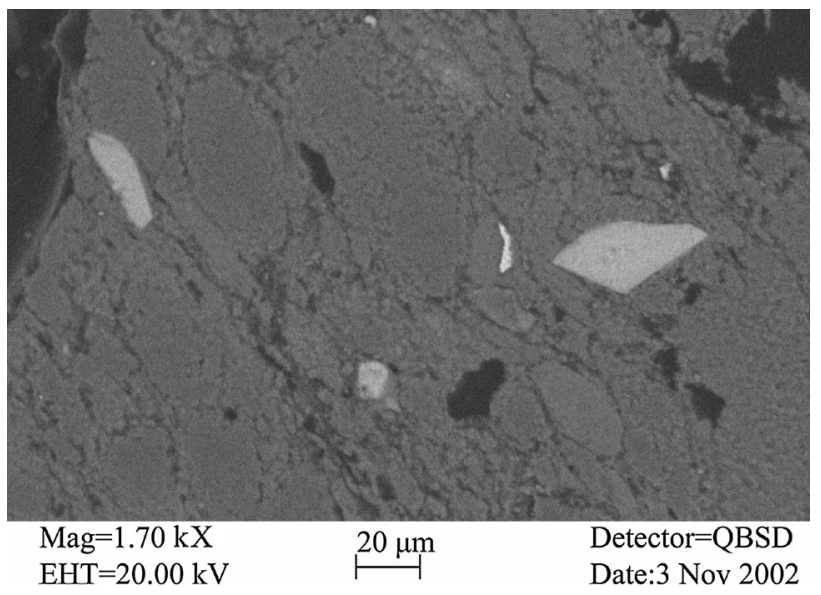

Fig. 3 Fine-grain rutile in the kaolinite (SEM backscattered electron image)

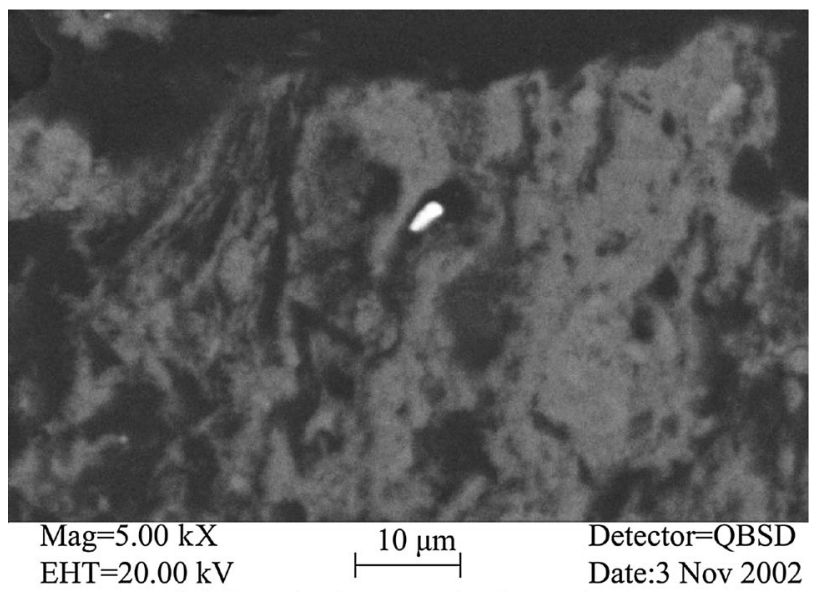

(a) SEM backscattered eelctron image

Spectrum: HDG 12 Hange: $20 \mathrm{keV}$

Total Cnts $=10,864 \quad$ Linear Auto-VS=184

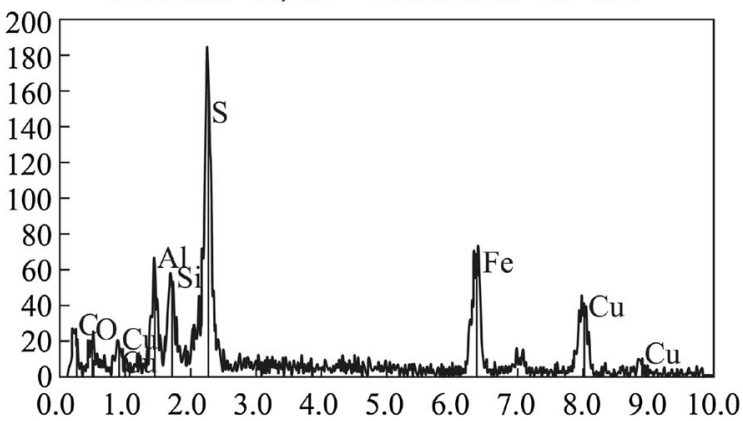

(b) X-ray spectrum diagram, spot scan

Fig. 4 Fine grain chalcopyrite in the kaolinite

area scanning. Backscattered electron images (BSE) of the minerals were then obtained. The mineral compositions were determined by EDS both qualitatively and 


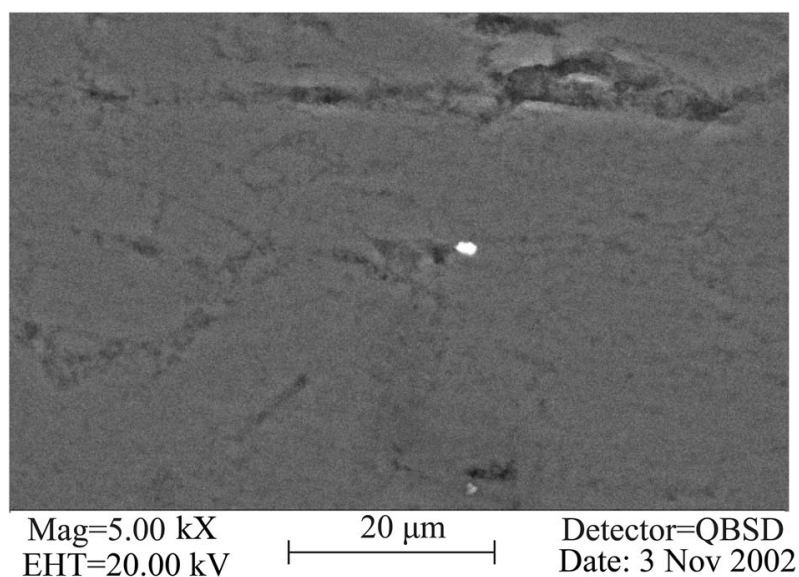

(a) SEM backscattered electron image

Spectrum:HDG 09 Hange:20 keV

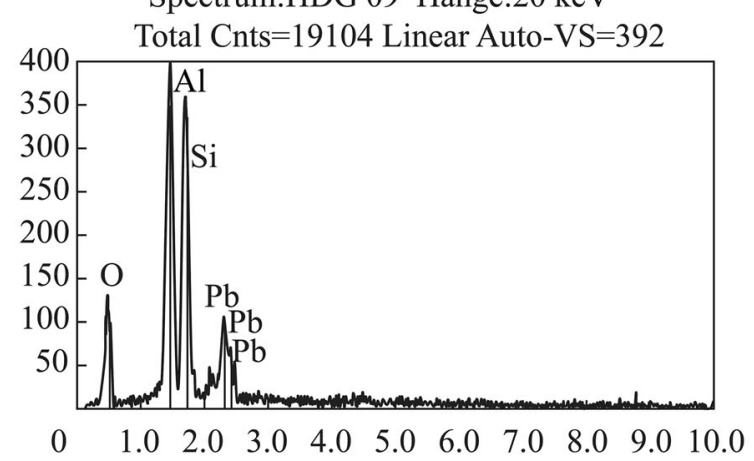

(b) X-ray energy spectrum diagram, spot scan

Fig. $5 \mathrm{~Pb}$-bearing minerals in the kaolinite

quantitatively. The acquisition time for the EDS analysis was $50 \mathrm{~s}$ and the scanned areas were determined by the size and morphology of the mineral particles.

\subsection{Distributions and occurrence of the trace elements}

\subsubsection{Determination of the trace elements}

The concentrations of $\mathrm{Ag}, \mathrm{As}, \mathrm{B}, \mathrm{Ba}, \mathrm{Be}, \mathrm{Cd}, \mathrm{Co}, \mathrm{Cr}, \mathrm{Cs}$, $\mathrm{Cu}, \mathrm{F}, \mathrm{Ga}, \mathrm{Ge}, \mathrm{Hg}, \mathrm{Mn}, \mathrm{Mo}, \mathrm{Ni}, \mathrm{P}, \mathrm{Pb}, \mathrm{Sb}, \mathrm{Sc}, \mathrm{Se}, \mathrm{Sn}, \mathrm{Sr}$, Ta, Th, Ti, U, V, W, Y, Yb, Zn in the No. 6 coal seam were determined.

The trace elements were determined by inductively coupled-plasma mass spectrometry (ICP-MS) except for As, F, Ge, Hg, Sb and Se. For ICP-MS analysis the samples were digested using a microwave high pressure reactor. $\mathrm{F}$ was determined by pyrohydrolysis in conjunction with a fluoride ion-selective electrode according to GB/T35581996. Hydride generation atomic fluorescence spectrometry analysis (HGAFS) was used to determine the concentrations of $\mathrm{As}, \mathrm{Ge}, \mathrm{Sb}$ and $\mathrm{Se}$ while cold-vapor atomic fluorescence spectrometry analysis (CVAFS) was used to determine the concentration of $\mathrm{Hg}$.

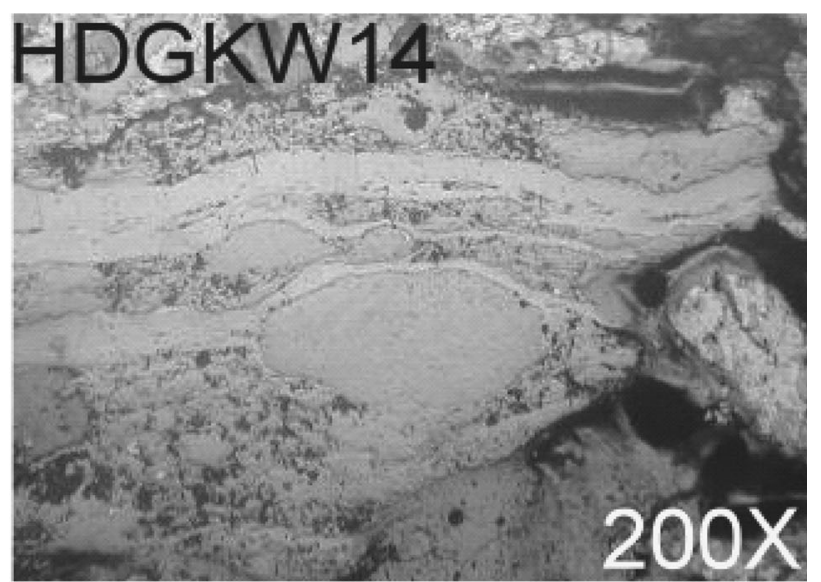

(a) Optical microscopy image, reflected light, air, individual particle



(b) SEM backscattered electron image

Spectrum: HDG 05 Hange: $20 \mathrm{keV}$

Total Cnts $=21,205$ Linear auto-VS $=1,042$

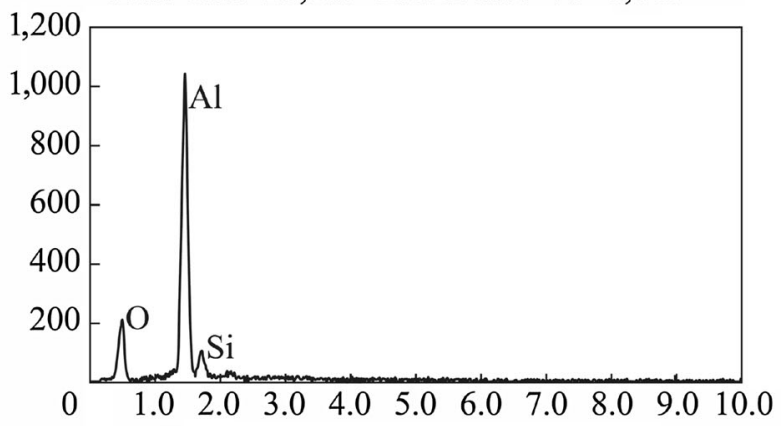

(c) X-ray energy spectrum diagram, scaaned area: $150 \mu \mathrm{m} \times 150 \mu \mathrm{m}$

Fig. 6 Bauxite in Heidaigou coal

\subsubsection{Occurrence of the trace elements}

The coal samples were crushed to less than $3 \mathrm{~mm}$ and fine particles of less than $0.5 \mathrm{~mm}$ were collected. Float-sink 


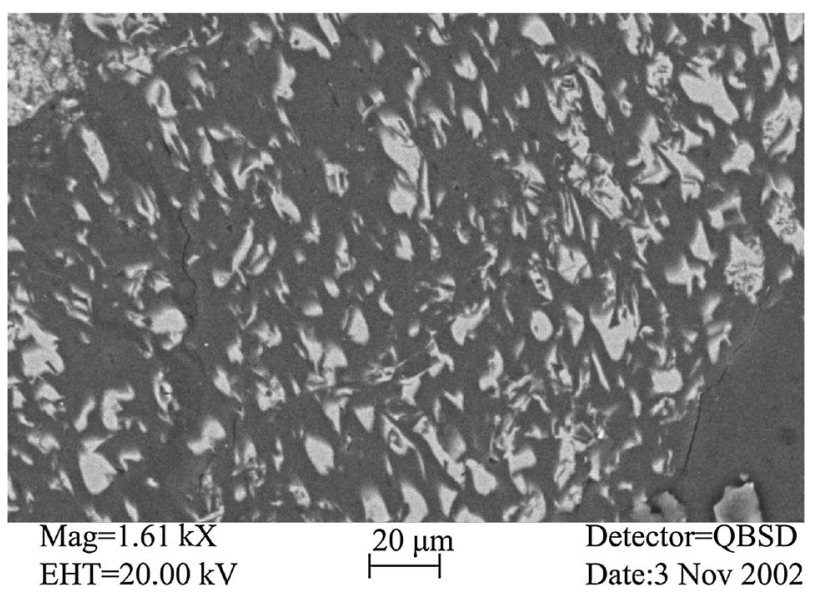

(a) SEM backscattered electron image

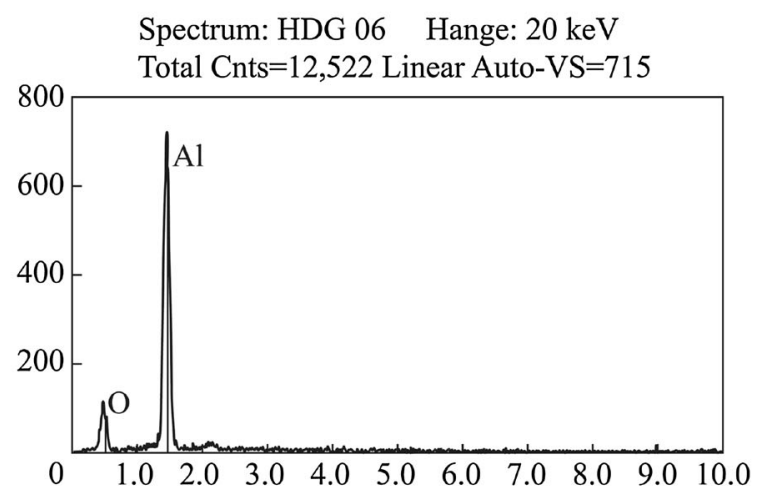

(b) X-ray energy spectrum diagram, spot scan

Fig. 7 Bauxite in the fusinite lumens

experiments were conducted using particles between 3 and $0.5 \mathrm{~mm}$ following the Chinese standard GB/T478-2008. The ash and sulfur content, the maceral groups and minerals (divided into clay minerals, pyrite, quartz and carbonates) and the contents of $\mathrm{As}, \mathrm{B}, \mathrm{Be}, \mathrm{Ga}, \mathrm{Ge}, \mathrm{Hg}, \mathrm{Mn}$, Mo, P, Sc, Sr, Ta, Th, Ti, V, W, Y, Yb were determined in products of different densities and in the fines of particle size less than $0.5 \mathrm{~mm}$. The precision of the float-sink experiment and the determination of the trace elements were evaluated by balancing the trace element content between the raw coal and the weighted mean values in the products of different densities in the float-sink experiments and in the fines of particle size less than $0.5 \mathrm{~mm}$. The calculation was conducted according to Eq. (1):

$R=\sum_{j=1}^{n} C_{j} W_{j} / C$

where, $R$ is the ratio of the weight mean trace element content in the products of different densities and of that in raw coal (\%), $C$ is the content of trace elements in the raw coal $(\mu \mathrm{g} / \mathrm{g}), C_{j}$ is the content of trace elements in the products of a certain density including the fines of particle size less than $0.5 \mathrm{~mm}(\mu \mathrm{g} / \mathrm{g}), W_{j}$ is the yield of products of certain density including the fines of particle size less than $0.5 \mathrm{~mm}(\%)$.

The dominant mineral components are clay minerals and the pyrite content is low resulting in a simple mineral composition for the Heidaigou coal. The coal can be divided into vitrinite, inertinite and various minerals in terms of coal petrology while liptinite is ignored. The mass fraction of organic matter that consists of vitrinite and inertinite, the minerals in the raw coal and the products of different densities can be calculated according to Eqs. (2) and (3).

$M M=1.1 A_{\mathrm{d}}+0.5 S_{\mathrm{p}, \mathrm{d}}$

$O R G=100-M M$

where, $M M$ is the mineral content of the coal (mass fraction), $O R \mathrm{G}$ is the organic matter in the coal (mass fraction), $A_{\mathrm{d}}$ is the yield of ash in the coal (\%), $S_{\mathrm{p}, \mathrm{d}}$ is the pyritic sulfur content of the coal (\%).

Because the macerals and the minerals in the coal petrological analysis are expressed as volume fractions the densities of vitrinite, inertinite and the minerals were 1.33, 1.40 and $2.60 \mathrm{~g} / \mathrm{cm}^{3}$, respectively, for the calculation of mass fraction in this paper.

A linear relationship was found for the trace element content of the raw coal $\left(C_{\mathrm{m}}\right)$ and for the different macerals and minerals $\left(C_{\mathrm{mi}}\right)$. The theoretical trace element $\left(C_{\mathrm{mi}}\right)$ content of the macerals and the minerals was calculated by multi-factor linear regression of the maceral and mineral compositions $\left(W_{\mathrm{mi}}\right)$. The trace element $\left(C_{\mathrm{m}}\right)$ content of the products of different densities were determined using Eq. (4):

$C_{\mathrm{m}}=\sum_{i=1}^{n} C_{\mathrm{mi}} W_{\mathrm{mi}}$

where, $C_{\mathrm{m}}$ is the content of a specific element in the coal $(\mu \mathrm{g} / \mathrm{g}), C_{\mathrm{mi}}$ is the theoretical content of a specific element in vitrinite, inertinite and in the minerals $(\mu \mathrm{g} / \mathrm{g})$, and $W_{\mathrm{mi}}$ is the maceral composition of the products of different densities (\%).

The amount of trace elements in the organic matter of the coal can be expressed by organic affinity. The organic affinity index $\left(A_{\mathrm{o}}\right)$ of different trace elements in the coal was calculated using Eq. (5):

$A_{o}=C_{o} W_{o} / C$

where, $C_{\mathrm{o}}$ is the average content of a specific trace element in the organic matter $(\mu \mathrm{g} / \mathrm{g}), C$ is the content of trace elements in the raw coal $(\mu \mathrm{g} / \mathrm{g})$, and $W_{\mathrm{o}}$ is the content of organic matter in the coal (mass fraction). 


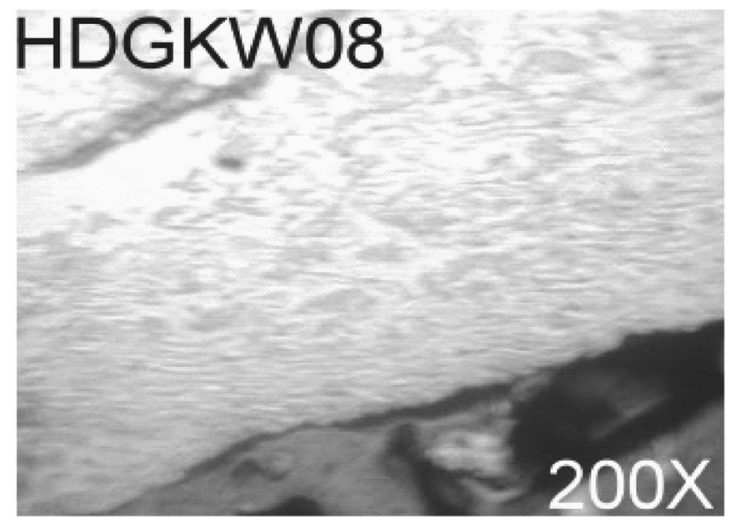

(a) Optical microscopy image, refected light, air, polarized light

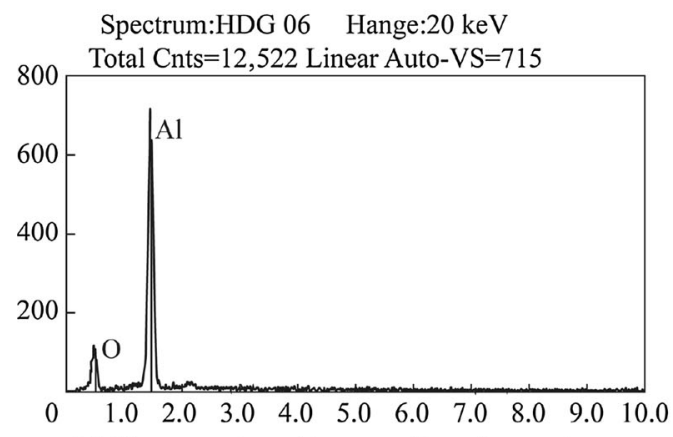

(c) X-ray spectrum idagram of bauxite, spot scan

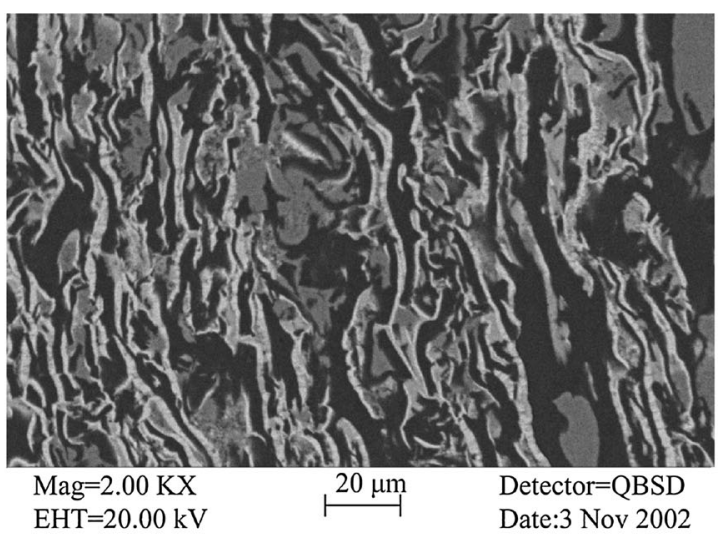

(b) SEM backscattered electron image

Spectrum:HDG 13 Hange:20 keV

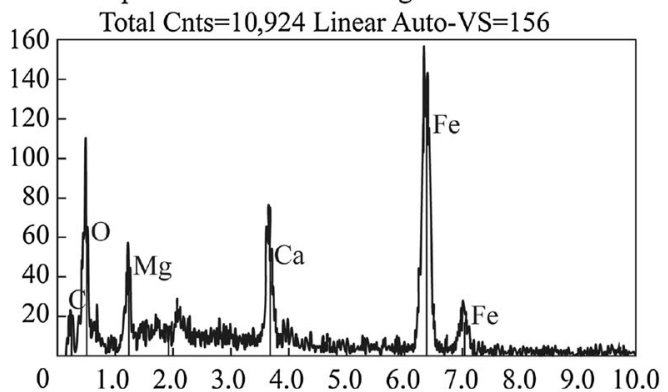

(d) X-ray energy spectrum diagram of the carbonates, spot scan

Fig. 8 Bauxite intergrown with carbonates

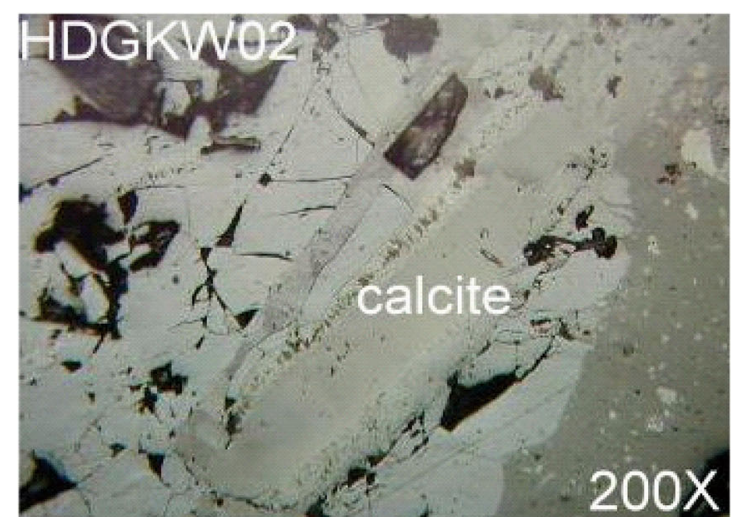

(a) Optical microscopy image, reflected light, air, polarized light

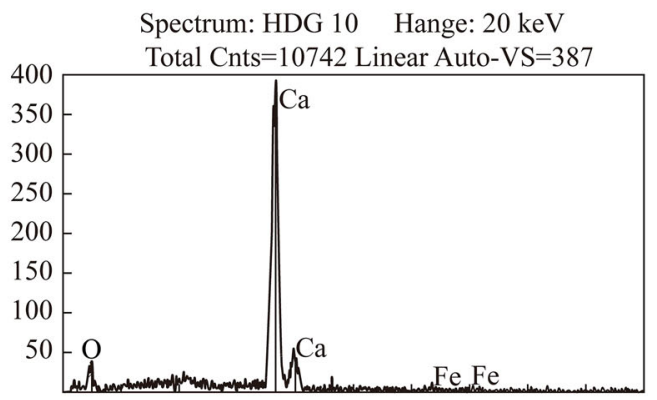

$\begin{array}{lllllllllll}0 & 1.0 & 2.0 & 3.0 & 4.0 & 5.0 & 6.0 & 7.0 & 8.0 & 9.0 & 10.0\end{array}$

(c) X-ray energy spectrum diagram of calcite, spot scan

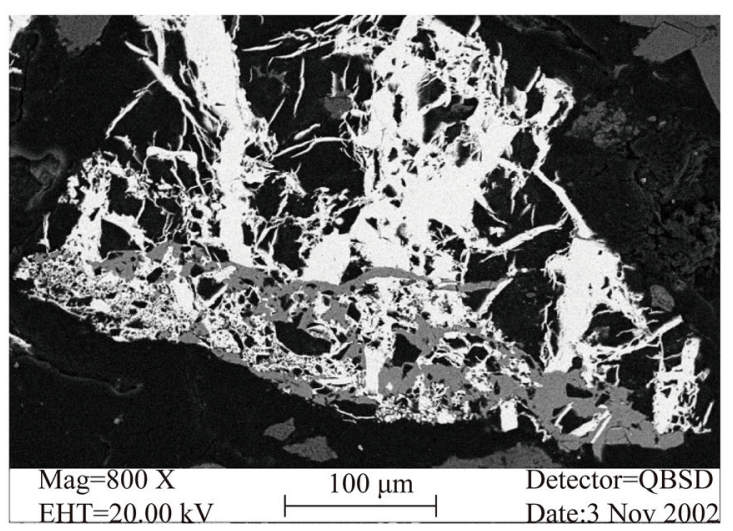

(b) SEM backcattered electron image

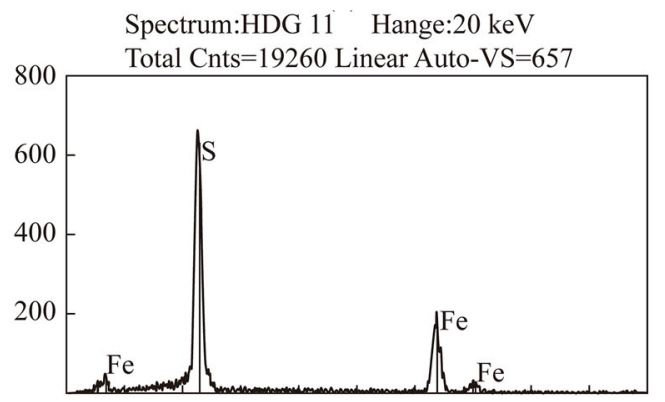

$\begin{array}{lllllllllll}0 & 1.0 & 2.0 & 3.0 & 4.0 & 5.0 & 6.0 & 7.0 & 8.0 & 9.0 & 10.0\end{array}$

(d) S-ray energy spectrum diagram of pyrite, spot scan

Fig. 9 Pyrite and calcite that fill fractures 


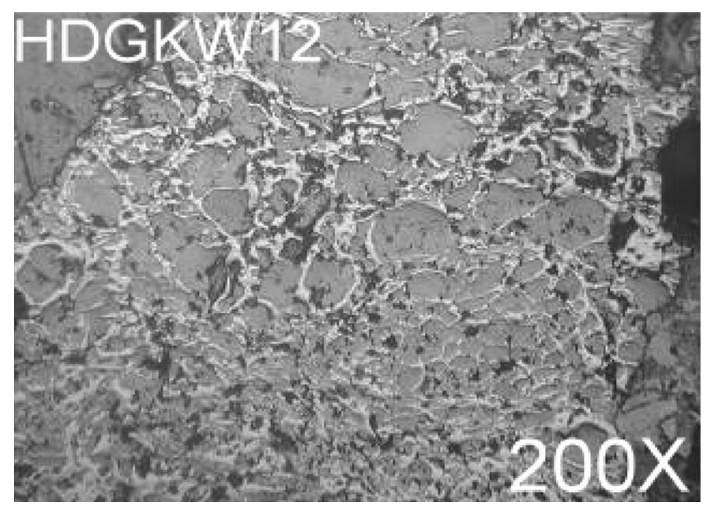

Fig. 10 Calcite in the fusinite lumens (reflected light; air; polarized light; $\times 200$

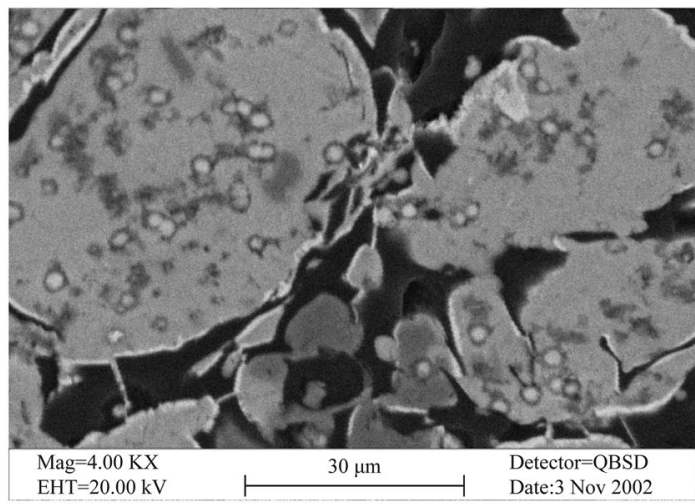

(a) Backscattered electron images of goyazite and calcite ( $\mathrm{Fe}$ and $\mathrm{Mg}$ are enriched at the edge)

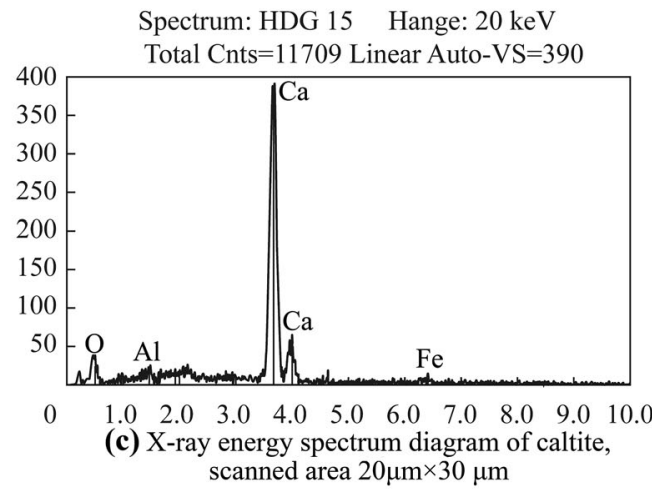

\subsection{Removability of the trace elements}

The theoretical degree of trace element removal depends on the organic affinity and on fine coal recovery. It is the ratio of trace element content in waste coal to that in raw coal. Suitable separation density and trace element washability was obtained by float-sink experiments. The theoretical degree of trace element removal from the coal preparation can be calculated using Eq. (6).

$\lambda=\left(C-C_{\mathrm{r}} \times F C R\right) / C$

where, $\lambda$ is the theoretical degree of trace element removal $(\%), C$ is the trace element content of the raw coal $(\mu \mathrm{g} / \mathrm{g})$,

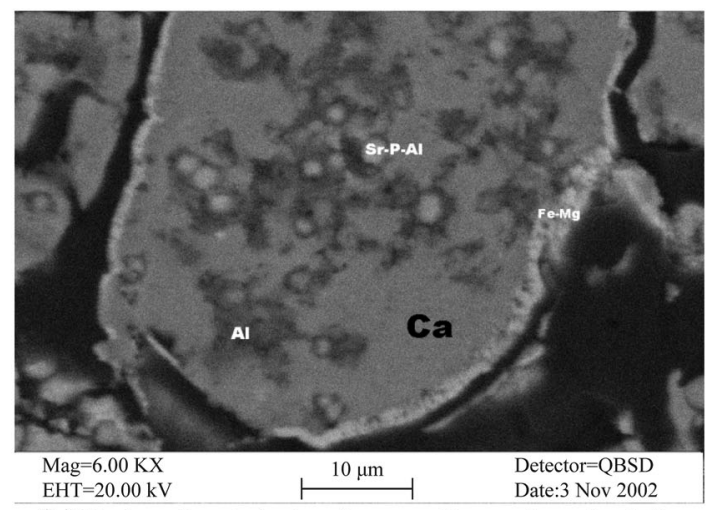

(b) Backscattered electron images of goyazite and calcite (Fe and $\mathrm{Mg}$ are enriched at the edge)

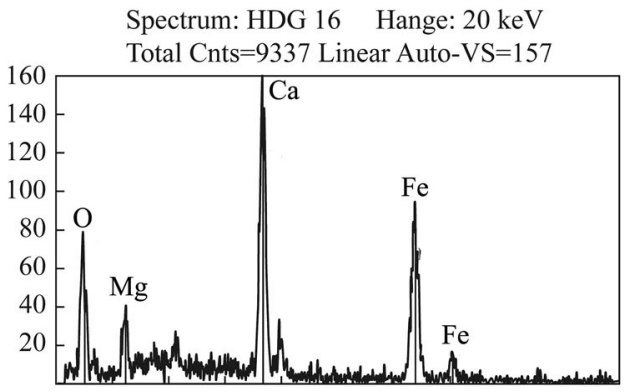

$\begin{array}{llllllllllll}0 & 1.0 & 2.0 & 3.0 & 4.0 & 5.0 & 6.0 & 7.0 & 8.0 & 9.0 & 10.0\end{array}$

(d) X-rya energy spectrum diagram of $\mathrm{Fe}$ and $\mathrm{Ma}$ at the edge of the calcite particle, spot scan

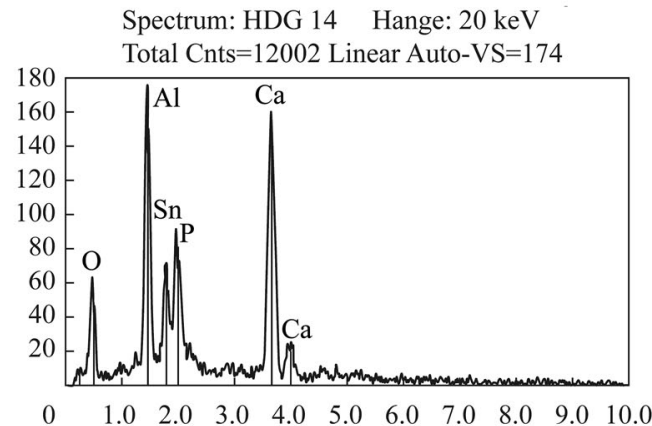

(e) X-ray energy spectrum diagram of goyazite in the calcite particle, spot scan

Fig. 11 Calcite and goyazite (bean-like) in the fusinite lumens 


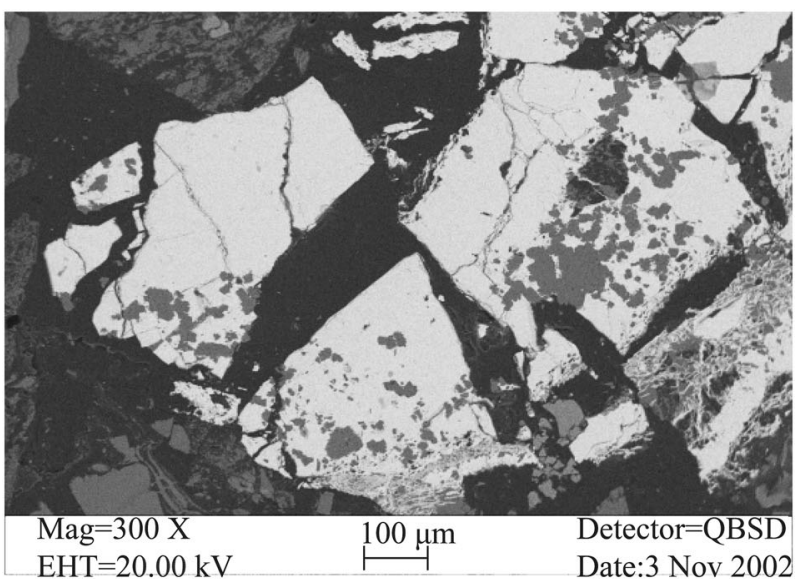

(a) Backscattered electron image of marcasite

Spectrum: HDG 07 Hange: $20 \mathrm{keV}$

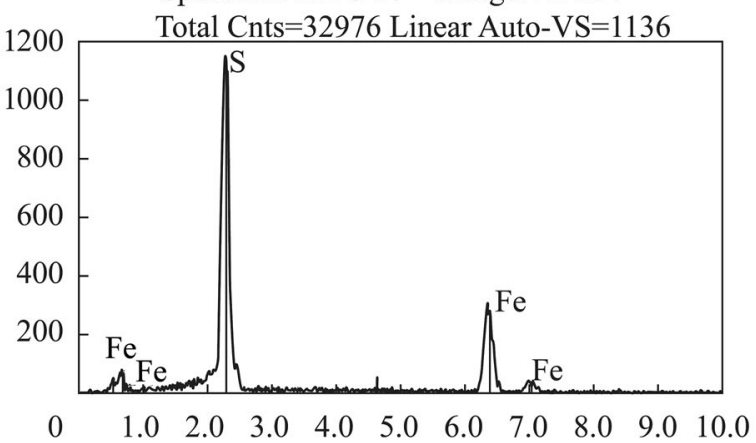

(b) X-ray energy spectrum diagram of marcasite

Fig. 12 Marcasite in Heidaigou coal

$C_{\mathrm{r}}$ is the trace element content of the clean coal $(\mu \mathrm{g} / \mathrm{g})$, $F C R$ is the fine coal recovery $(\%)$.

\section{Results and discussions}

3.1 Mineralogical composition of No. 6 coal from Heidaigou mine

A high mineral content, dominated by kaolinite, was found in No. 6 coal from Heidaigou mine. Its bauxite content is relatively high while pyrite and quartz are low.

(1) Clay minerals Kaolinite is the main clay mineral in Heidaigou coal with some illite also present. Kaolinite is mainly dispersed in thin-layers or as individual particles (Fig. 1) and it is also found in the fusinite lumens. It appears uneven in reflected light with a gray-brown color and the kaolinite has a dim gray to yellow interference color under cross-polarized reflected light. The interference color changes slightly when the stage is rotated. The $\mathrm{Si} / \mathrm{Al}$ ratio of Kaolinite is between 0.9 and 1.1 (Table 7) indicating a relatively high $\mathrm{Al}$ content and a comparatively low $\mathrm{Si}$ content. A low impurity content of zircon (Fig. 2), rutile (Fig. 3), chalcopyrite (Fig. 4) and Pb-bearing minerals (Fig. 5) was found in the Kaolinite by SEM-EDX analyses.

(2) Bauxite The presence of bauxite in Heidaigou coal results in a relatively high $\mathrm{Al}_{2} \mathrm{O}_{3}$ content for the coal ash $(57.18 \%)$ and a high coal ash fusion temperature (temperature higher than $1,500{ }^{\circ} \mathrm{C}$ ). A gray reflection color and an uneven surface were found for bauxite while a dim gray-yellow or no interference color was found when using cross-polarized reflected light. The interference color does not change when the stage is rotated. Therefore, it is difficult to distinguish bauxite from kaolinite using optical microscopy. Individual particles (Fig. 6) are the main form of bauxite, which is also found in the fusinite lumens (Fig. 7) and it is intimately intergrown with carbonate minerals (Fig. 8).

(3) Carbonates The carbonate mineral content is relatively high and the dominant mineral is calcite. Calcite mainly fills fractures (Fig. 9a) and cell cavities (Figs. 10, 11a, c). Some calcite was intimately intergrown with pyrite (Fig. 9b) and bauxite (Fig. 8). A significant amount of $\mathrm{Fe}$ and $\mathrm{Mg}$ that probably displaced $\mathrm{Ca}$ as isomorphs were found at the edge of the calcite (Fig. 11b, d). Small amounts of impure minerals such as irregular Al-bearing minerals and bean-like goyazite were found in the calcite particles (Fig. 11b, e).

(4) Sulfides The sulfide content mainly comes from sulfides such as pyrite and it is low in coal. The pyrite mainly fills fractures (Fig. 9b) or disseminates in the fine grains. Some marcasite is present in the coal (Fig. 12). A similar yellowishwhite reflected color was obtained for marcasite and pyrite when subjected to polarized light and it is thus difficult to distinguish marcasite from pyrite. Marcasite presents obvious anisotropy and it has a parallel twin structure and a dim gray-shallow celadon interference color in cross-polarized reflected light, which is significantly different to that of pyrite (Fig. 13).

3.2 Distributions and occurrence of trace elements in No. 6 coal from Heidaigou mine

\subsubsection{Trace element concentrations in the coal samples}

The concentrations of 33 trace elements in No. 6 coal from Heidaigou mine were compared to average values of 


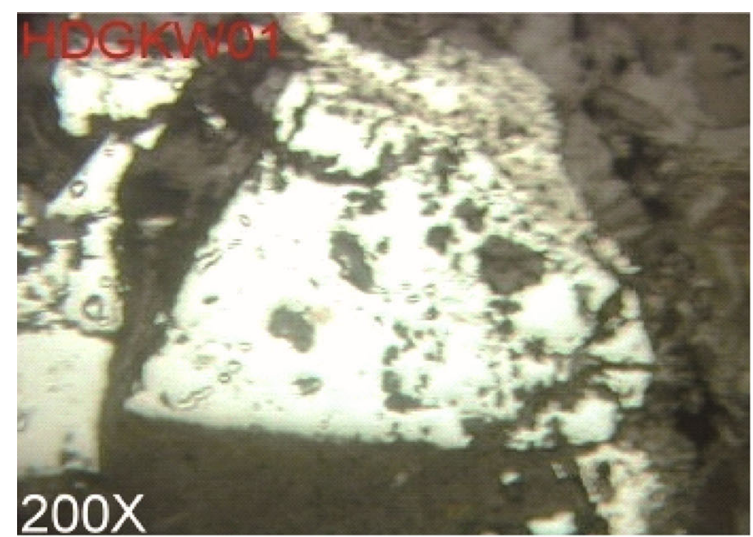

(a) Refected plane-polarized light

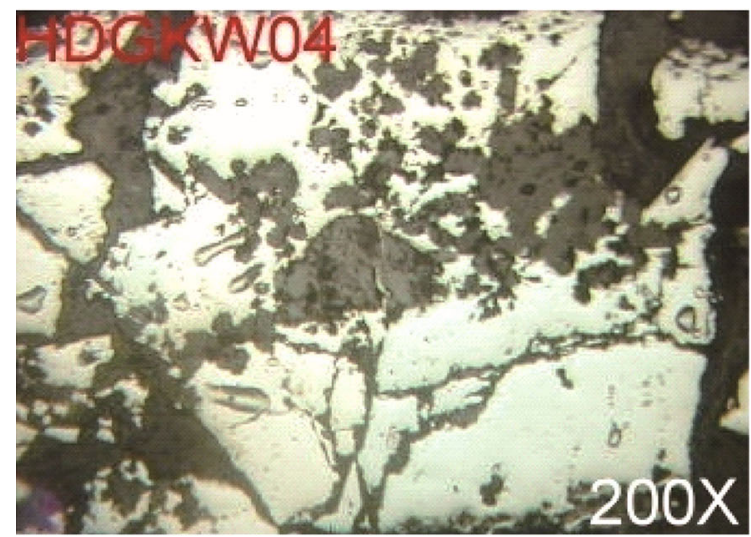

(c) Refected plane-polarized light

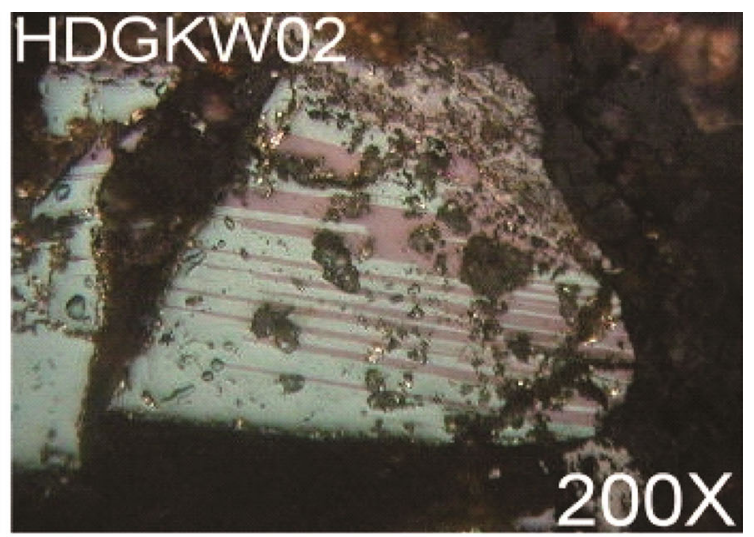

(b) Corresponding image in cross-polarized light, air

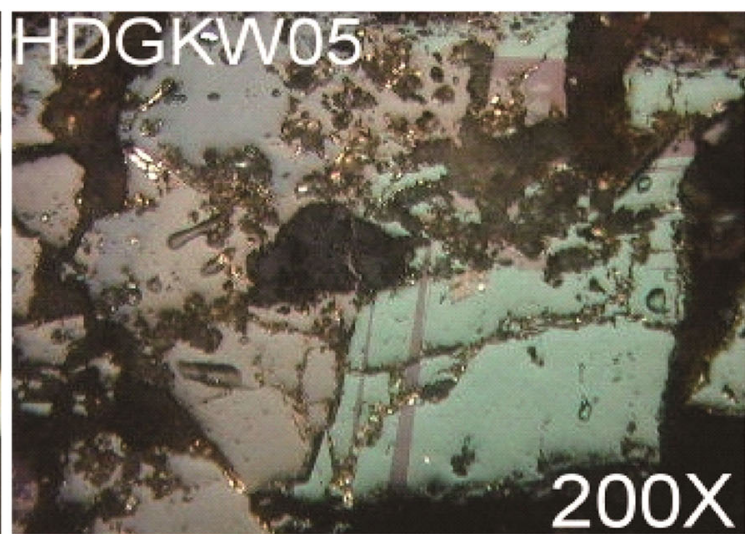

(d) Corresponding image in cross-polarized light, air

Fig. 13 Comparison between marcasite upon receiving reflected plane-polarized light and cross-polarized light

these trace elements in Chinese and international coals and the data are listed in Table 8. Compared to the average values of trace elements in Chinese coals, the weighted value of the trace elements in Heidaigou coal is relatively low. The concentrations of $\mathrm{Ta}, \mathrm{Ga}, \mathrm{Hg}, \mathrm{Th}, \mathrm{Se}$, $\mathrm{Pb}, \mathrm{U}$ and $\mathrm{Ti}$ are 1.5-3 times higher than the average of these elements in Chinese coals while the $\mathrm{W}, \mathrm{Y}, \mathrm{P}, \mathrm{Sr}$ contents are almost the same as the average concentrations in Chinese coals. The concentrations of the other trace elements are lower than those in Chinese coals. Compared to the average values of trace elements in international coals the concentrations of $\mathrm{Se}, \mathrm{Ta}, \mathrm{Ti}, \mathrm{Th}, \mathrm{Hg}$, $\mathrm{Pb}, \mathrm{Ga}$ are 3-5 times higher while $\mathrm{Sr}, \mathrm{Yb}$, and $\mathrm{U}$ are only slightly higher. Concentrations of Y, W, F, V, Sc, P, Be are almost the same as the average content of these elements in international coals. The concentrations of the other trace elements are lower than those in international coals. The ratios of these elemental concentrations in Heidaigou coal to Chinese coals and international coals are shown in Figs. 14 and 15.

\subsubsection{Occurrence of trace elements in No. 6 coal from Heidaigou mine}

The maceral composition and the content of 18 trace elements in the products from the float-sink experiments are listed in Table 9. The maceral compositions in the products of different densities are shown in Fig. 16. The precision of the float-sink experiments was in accordance with GB/T 478-2008, as shown by the balanced ash and sulfur content calculations. The $R$ values of most trace elements were between $50 \%$ and $150 \%$, which are acceptable for trace elements in float-sink experiments (Querol et al. 2001; Reed et al. 2001). The dark reflectance colors of clay minerals and quartz make a quantitative determination in oil immersed reflected light difficult, which results in deviations in the results of the balance calculations.

As shown in Table 9: As, Ga, Hg, Mn, Mo, Ta, Ti, W concentrate in the heavy density products and, therefore, these trace elements are probably present in the minerals. $\mathrm{B}, \mathrm{P}, \mathrm{Sr}, \mathrm{V}, \mathrm{Y}, \mathrm{Yb}$ are mainly present in the organic matter. 
Table 8 Element concentrations in No. 6 coal from Heidaigou mine $(\mu \mathrm{g} / \mathrm{g})$

\begin{tabular}{|c|c|c|c|}
\hline Element & Concentrations & China coal* & World coal** \\
\hline $\mathrm{Ag}$ & 0.02 & 0.04 & 0.095 \\
\hline As & 1.34 & 4.09 & 8.3 \\
\hline B & 32.21 & $53 * * * *$ & 52 \\
\hline $\mathrm{Ba}$ & 18.1 & 270 & 150 \\
\hline $\mathrm{Be}$ & 1.51 & 1.75 & 1.6 \\
\hline $\mathrm{Cd}$ & 0.06 & 0.81 & 0.22 \\
\hline Co & 1.24 & 10.62 & 5.1 \\
\hline $\mathrm{Cr}$ & 3.00 & 16.94 & 16 \\
\hline $\mathrm{Cs}$ & 0.10 & 1.51 & 1.0 \\
\hline $\mathrm{Cu}$ & 12.53 & 17.87 & 16 \\
\hline $\mathrm{F}$ & 100 & 157 & 88 \\
\hline $\mathrm{Ga}$ & 19.06 & 6.84 & 5.8 \\
\hline $\mathrm{Ge}$ & 0.09 & 2.43 & 2.2 \\
\hline $\mathrm{Hg}$ & 0.413 & 0.154 & 0.10 \\
\hline Mn & 40.9 & $271.22 * * * *$ & 50 \\
\hline Mo & 1.31 & 2.70 & 2.2 \\
\hline $\mathrm{Ni}$ & 3.13 & 14.44 & 13 \\
\hline $\mathrm{P}$ & 219.90 & 216 & 230 \\
\hline $\mathrm{Pb}$ & 31.63 & 16.64 & 7.8 \\
\hline $\mathrm{Sb}$ & 0.09 & 0.71 & 0.92 \\
\hline Sc & 3.90 & 4.40 & 3.9 \\
\hline $\mathrm{Se}$ & 7.09 & 2.82 & 1.3 \\
\hline $\mathrm{Sn}$ & 0.51 & $2.11 * * *$ & 1.1 \\
\hline $\mathrm{Sr}$ & 178.0 & 195 & 110 \\
\hline $\mathrm{Ta}$ & 1.42 & 0.40 & 0.28 \\
\hline $\mathrm{Th}$ & 15.31 & 5.88 & 3.3 \\
\hline $\mathrm{Ti}$ & 2,515 & $1,685 * * * *$ & 500 \\
\hline $\mathrm{U}$ & 3.51 & 2.33 & 2.4 \\
\hline V & 27.59 & 51.18 & 25 \\
\hline W & 1.28 & 1.05 & 1.1 \\
\hline $\mathrm{Y}$ & 10.68 & 9.07 & 8.4 \\
\hline $\mathrm{Yb}$ & 1.58 & 1.76 & 1.0 \\
\hline $\mathrm{Zn}$ & 18.0 & $41.4 * * *$ & 23 \\
\hline
\end{tabular}

* Bai et al. (2007)

** Ketris and Yudovich (2009)

*** Dai et al. (2012)

$* * * *$ Ren et al. (1999)

$\mathrm{B}$ and $\mathrm{V}$ are mainly present in vitrinite while $\mathrm{P}, \mathrm{Sc}, \mathrm{Sr}, \mathrm{Y}$, $\mathrm{Yb}$ are present in inertinite. Be and Th are mainly present in inertinite with small amounts found in the minerals. Ge is evenly distributed in the minerals and in the organic matter.

The trace element content of the products of different densities of the No. 6 coal from Heidaigou mine is shown in Fig. 17. The contents of As and Hg in the products of different densities have the same trend as the change in density. This is also the case for Ga, Ta, W, Ti and Mn. The trend for these elements is the same as that of the minerals upon a change in density. Therefore, these trace elements are probably present in the minerals. As the density changes the $\mathrm{B}$ and $\mathrm{V}$ content of the products of different densities have the same trend as that of vitrinite. Therefore, these trace elements are probably present in the vitrinite. The Be, Th, P, Sc, Yb, Y and Sr content of the products of different densities have the same trend as the change in density. This is the same as the behavior of inertinite. Therefore, these trace elements are probably present in the inertinite.

(1) Correlation analyses The relationship between the trace element content and the maceral groups, the ash content, and the sulfur content are listed in Table 10 respectively. The content of trace elements, vitrinite, inertinite, clay minerals, pyrite, quartz, carbonates, ash and sulfur in the 6 products of different densities that were obtained from the floatsink experiments, raw coal and the fines of less than $0.5 \mathrm{~mm}$ were used to calculate the correlation coefficients. A significant positive correlation exists between As and the ash content, the sulfur content, the clay mineral content, and the pyrite at a confidence level of $95 \%$ (critical correlation coefficient $R=0.7068$ ). This is also the case for $\mathrm{Hg}$ and Mo. A significant positive correlation was found between $\mathrm{Ga}$ and the ash content, the clay mineral content, the quartz content and the carbonates content. It had a negative correlation with virtrinte and liptinite. This was also the case for $\mathrm{Ta}, \mathrm{Ti}$ and W. A positive correlation was found between $\mathrm{Mn}$ and the carbonates content while a negative correlation exists between $\mathrm{Mn}$ and virtrinte. Significant negative correlations exist between $\mathrm{Sr}$ and the ash content, the sulfur content, the clay mineral content and the pyrite content. This was also the case for $\mathrm{Y}$ and $\mathrm{Yb}$. A significant positive correlation existed between $\mathrm{Be}$ and inertinite and a negative correlation with the sulfur content. This was also the case for $\mathrm{P}$, Sc and Th. A significant positive correlation existed between $\mathrm{B}$ and virtrinte and a negative correlation exists with inertinite. A significant positive correlation exists between $\mathrm{V}$ and virtrinte and a negative correlation exists with the minerals. A significant positive correlation exists between Ge and the sulfur content. The correlation coefficients of the trace elements are listed in Table 11. A significant positive correlation exists among $\mathrm{As}, \mathrm{Hg}$, Mo and Ge. This is also the case among Ga, Ta, Ti, W, Mn, among Be, Th, $\mathrm{P}, \mathrm{Sc}, \mathrm{Sr}, \mathrm{Y}, \mathrm{Yb}$ and between $\mathrm{B}$ and 


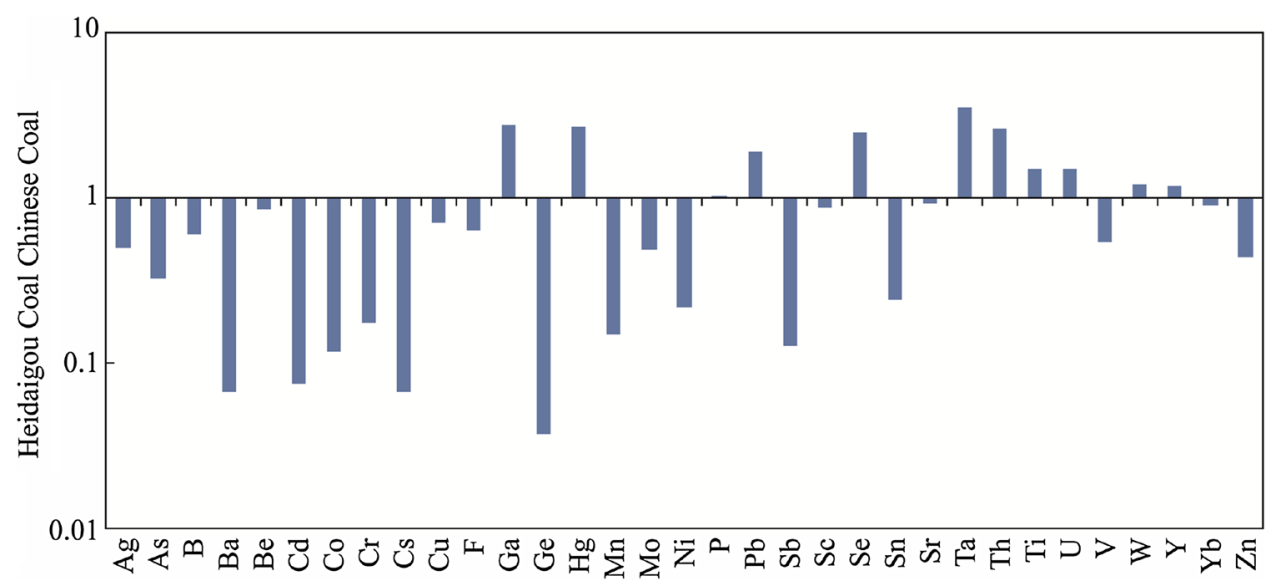

Fig. 14 Comparisons between the concentrations of trace elements in Heidaigou coal and those in other Chinese coals

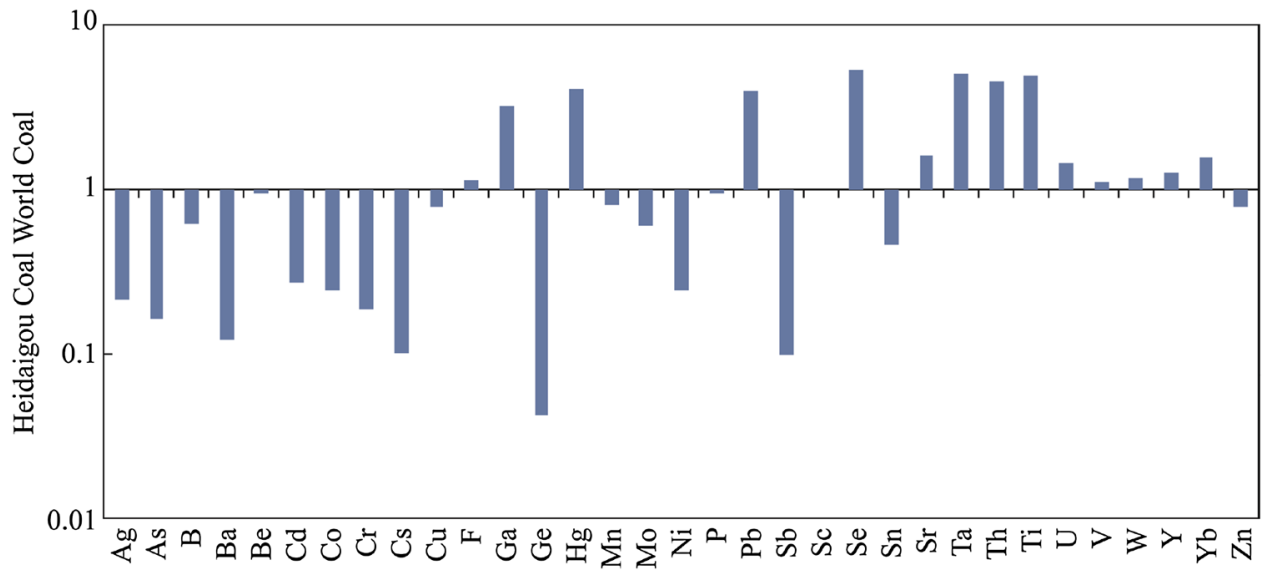

Fig. 15 Comparisons between the concentrations of trace elements in Heidaigou coal and those in international coals

V. High correlation coefficients indicate that these grouped elements have a similar occurrence. As, $\mathrm{Hg}$, $\mathrm{Mo}, \mathrm{Ge}, \mathrm{Ga}, \mathrm{Ta}, \mathrm{Ti}, \mathrm{W}, \mathrm{Mn}$ are mainly concentrated in the minerals while $\mathrm{Be}, \mathrm{Th}, \mathrm{P}, \mathrm{Sc}, \mathrm{Sr}, \mathrm{Y}, \mathrm{Yb}, \mathrm{B}, \mathrm{V}$ are mainly found in the organic matter according to the correlation analyses of the trace elements and between the trace elements and the maceral groups.

(2) Theoretical trace element content in the maceral groups and the minerals in No. 6 coal from Heidaigou mine The trace element content of the maceral groups and of the minerals can be calculated using float-sink experiments and statistical methods, which is of great importance in determining the trace element occurrence and their behavior during coal processing and conversion. The theoretical content of trace elements in the maceral groups and in the minerals of No. 6 coal from Heidaigou mine are listed in Table 12. A ternary diagram showing the distribution of trace elements is given in Fig. 18. As, Ga, Hg, Mn, Mo, Ta, Ti, W are obviously concentrated in the minerals with low concentrations found in organic matter. $\mathrm{B}, \mathrm{Be}, \mathrm{P}$, $\mathrm{Sc}, \mathrm{Sr}, \mathrm{Th}, \mathrm{V}, \mathrm{Y}, \mathrm{Yb}$ are concentrated in the organic matter. $\mathrm{B}$ and $\mathrm{V}$ are mainly present in virtrinte while $\mathrm{Be}, \mathrm{P}, \mathrm{Sc}, \mathrm{Sr}, \mathrm{Th}, \mathrm{Y}, \mathrm{Yb}$ are present in inertinite. The Ge content of the minerals and of the organic matter is similar, which indicates an even distribution of $\mathrm{Ge}$ in the minerals and in the organic matter (no significant correlation from an $\mathrm{F}$ test).

(3) Organic affinities of the trace elements in No. 6 coal from Heidaigou mine The organic affinities of the trace elements in No. 6 coal from Heidaigou mine are listed in Table 13. The value for Ta in the raw coal was obtained from a weighted mean value of Ta in the different density products. As shown in Table 13, most of the trace elements are associated with the organics except for $\mathrm{As}, \mathrm{Hg}, \mathrm{Mn}, \mathrm{Ta}$, and $\mathrm{W}$. 
Table 9 Maceral compositions and concentrations of 18 trace elements in the products from the float-sink experiments

\begin{tabular}{|c|c|c|c|c|c|c|c|c|c|}
\hline Size grade $(\mathrm{mm})$ & $3-0.5$ & & & & & & $<0.5$ & Raw coal & $R(\%)$ \\
\hline Yield of production $(\%)$ & 54.44 & & & & & & 45.56 & & \\
\hline Density level (kg/L) & -1.30 & $1.3-1.4$ & $1.4-1.5$ & $1.5-1.6$ & $1.6-1.8$ & +1.80 & & & \\
\hline Yield of products of different density $(\%)$ & 6.29 & 31.12 & 19.82 & 13.34 & 8.46 & 20.97 & & & \\
\hline \multicolumn{10}{|l|}{ Coal quality } \\
\hline$A_{\mathrm{d}}(\%)$ & 2.62 & 7.13 & 14.47 & 23.89 & 34.67 & 68.11 & 23.15 & 24.67 & 99.36 \\
\hline$S_{\mathrm{t}, \mathrm{d}}(\%)$ & 0.53 & 0.46 & 0.34 & 0.27 & 0.33 & 0.85 & 0.44 & 0.49 & 94.91 \\
\hline \multicolumn{10}{|l|}{ Maceral group (vov\%) } \\
\hline Vitrinite & 79.09 & 40.54 & 14.21 & 10.56 & 8.53 & 5.99 & 27.62 & 31.87 & 80.13 \\
\hline Inertinite & 12.55 & 40.54 & 65.94 & 63.34 & 56.81 & 22.66 & 50.90 & 44.88 & 105.63 \\
\hline Liptinite & 7.27 & 13.21 & 5.10 & 3.84 & 0.91 & 0.75 & 4.69 & 8.78 & 63.56 \\
\hline Clay mineral & 0.55 & 4.82 & 12.75 & 17.66 & 28.13 & 59.93 & 15.16 & 11.87 & 156.17 \\
\hline Pyrite & 0.18 & 0.18 & 0.18 & 0.38 & 0.36 & 5.81 & 0.36 & 0.65 & 142.70 \\
\hline Quartz & 0.18 & 0.18 & 1.28 & 1.54 & 2.54 & 2.25 & 0.36 & 0.33 & 249.84 \\
\hline Carbonates & 0.18 & 0.54 & 0.55 & 2.69 & 2.72 & 2.62 & 0.90 & 1.63 & 72.81 \\
\hline \multicolumn{10}{|l|}{ Concentrations of trace element $(\mu \mathrm{g} / \mathrm{g})$} \\
\hline As & 0.95 & 0.95 & 0.95 & 0.95 & 0.95 & 5.97 & 0.95 & 1.34 & 113.97 \\
\hline B & 51.77 & 31.63 & 23.94 & 28.53 & 27.74 & 26.60 & 31.80 & 32.21 & 94.96 \\
\hline $\mathrm{Be}$ & 1.11 & 1.63 & 2.10 & 2.03 & 1.94 & 0.83 & 1.63 & 1.51 & 106.88 \\
\hline $\mathrm{Ga}$ & 14.73 & 14.76 & 15.27 & 19.86 & 25.05 & 27.10 & 18.99 & 19.06 & 99.65 \\
\hline $\mathrm{Ge}$ & 0.19 & 0.13 & 0.06 & 0.06 & 0.06 & 0.24 & 0.08 & 0.09 & 117.71 \\
\hline $\mathrm{Hg}$ & 0.063 & 0.091 & 0.113 & 0.155 & 0.175 & 0.971 & 0.342 & 0.412 & 76.62 \\
\hline $\mathrm{Mn}$ & 10.00 & 13.10 & 24.60 & 42.30 & 48.60 & 41.70 & 45.80 & 40.90 & 88.39 \\
\hline Mo & 1.32 & 1.05 & 0.98 & 1.10 & 1.37 & 2.02 & 1.21 & 1.31 & 95.72 \\
\hline $\mathrm{P}$ & 145.50 & 253.90 & 315.00 & 262.70 & 200.10 & 97.57 & 222.80 & 219.90 & 101.38 \\
\hline $\mathrm{Sc}$ & 2.19 & 4.28 & 5.40 & 5.11 & 3.75 & 0.95 & 5.48 & 3.90 & 116.20 \\
\hline $\mathrm{Sr}$ & 152.40 & 248.40 & 258.60 & 204.00 & 111.10 & 41.73 & 203.60 & 178.00 & 108.24 \\
\hline $\mathrm{Ta}$ & 0.32 & 0.58 & 1.02 & 1.29 & 1.91 & 2.51 & 1.39 & 1.42 & 93.24 \\
\hline Th & 4.90 & 14.10 & 21.33 & 17.57 & 16.07 & 8.21 & 15.73 & 15.31 & 97.83 \\
\hline $\mathrm{Ti}$ & $1,325.00$ & $1,661.00$ & $2,292.00$ & $2,632.00$ & $3,221.00$ & $3,298.00$ & $2,571.00$ & $2,515.00$ & 97.87 \\
\hline $\mathrm{V}$ & 48.11 & 30.81 & 27.60 & 28.05 & 29.86 & 16.51 & 29.75 & 27.59 & 104.01 \\
\hline W & 0.18 & 0.46 & 0.89 & 1.33 & 1.98 & 2.19 & 1.19 & 1.28 & 90.70 \\
\hline $\mathrm{Y}$ & 12.93 & 15.99 & 17.08 & 13.72 & 9.49 & 3.53 & 14.21 & 10.68 & 124.58 \\
\hline $\mathrm{Yb}$ & 1.51 & 1.80 & 2.06 & 1.79 & 1.45 & 0.53 & 1.74 & 1.58 & 103.09 \\
\hline
\end{tabular}

The balance calculations for the maceral groups are based on volume fraction

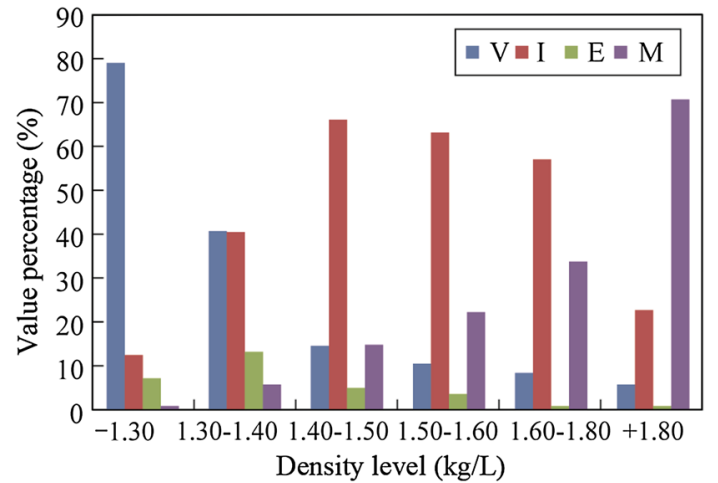

Fig. 16 Histogram of the maceral groups in the products of different densities
Their low organic affinity indicates that these elements are mainly integrated into an inorganic phase. It is worth noting that trace elements with high organic affinity are not necessary organically integrated because some trace elements were present in the fine grained minerals in the organic matter that filled the lumens.

3.3 Removal of trace elements during the coal preparation of No. 6 coal from Heidaigou mine

The washability curves of the trace elements were obtained during coal preparation of No. 6 coal from Heidaigou mine 

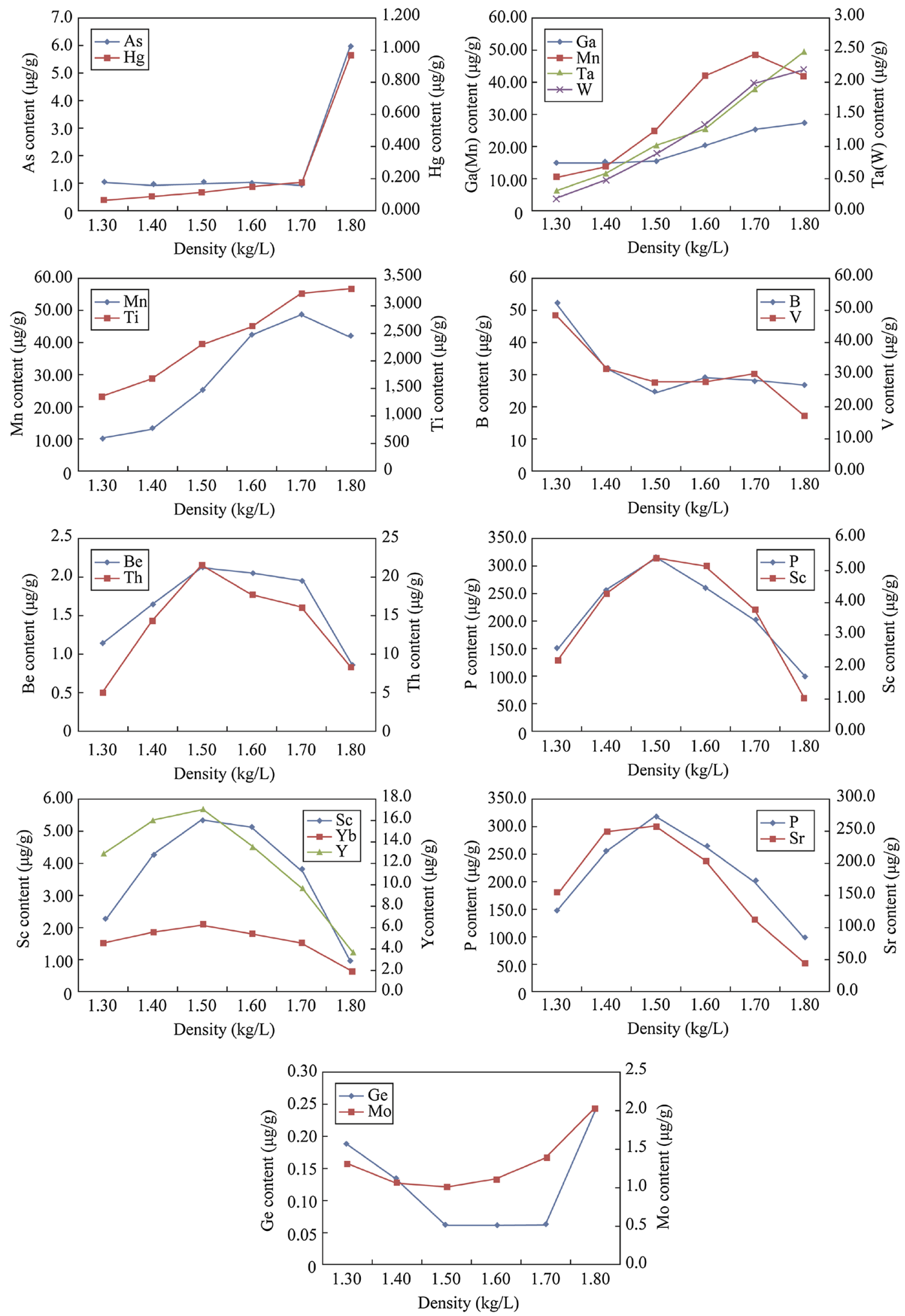

Fig. 17 Trace element content of the products of different densities from No. 6 coal from Heidaigou mine 
Table 10 Relationship between trace element content and the maceral group content, the mineral content, the ash content and the sulfur content

\begin{tabular}{|c|c|c|c|c|c|c|c|c|c|}
\hline Element & $A_{\mathrm{d}}$ & $S_{\mathrm{t}, \mathrm{d}}$ & Vitrinite & Inertinite & Liptinite & Clay mineral & Pyrite & Quartz & Carbonates \\
\hline As & 0.8676 & 0.8810 & -0.3512 & $-0.4,729$ & -0.4488 & 0.8905 & 0.9990 & 0.4708 & 0.4366 \\
\hline B & -0.5092 & 0.1370 & 0.9445 & -0.7056 & 0.3505 & -0.5078 & -0.2594 & -0.5762 & -0.5163 \\
\hline $\mathrm{Be}$ & -0.3976 & -0.9342 & -0.3833 & 0.9369 & 0.0176 & -0.3967 & -0.6935 & 0.1181 & 0.0530 \\
\hline $\mathrm{Ga}$ & 0.9323 & 0.4011 & -0.6666 & -0.0220 & -0.7861 & 0.9056 & 0.7019 & 0.8163 & 0.8776 \\
\hline $\mathrm{Ge}$ & 0.3744 & 0.9143 & 0.3432 & -0.9200 & -0.0179 & 0.4243 & 0.7266 & -0.0155 & -0.0705 \\
\hline $\mathrm{Hg}$ & 0.9047 & 0.8304 & -0.4204 & -0.3560 & -0.4554 & 0.8706 & 0.9392 & 0.3875 & 0.4869 \\
\hline $\mathrm{Mn}$ & 0.6685 & -0.0540 & -0.7474 & 0.4421 & -0.6863 & 0.5763 & 0.2755 & 0.5761 & 0.7903 \\
\hline Mo & 0.8581 & 0.8630 & -0.2093 & -0.5941 & -0.5389 & 0.8525 & 0.9184 & 0.4830 & 0.5038 \\
\hline$P$ & -0.5626 & -0.8124 & -0.2050 & 0.8307 & 0.3495 & -0.5597 & -0.6967 & -0.2154 & -0.2674 \\
\hline $\mathrm{Sc}$ & -0.5142 & -0.8395 & -0.2097 & 0.8488 & 0.2303 & -0.5431 & -0.7325 & -0.2555 & -0.2096 \\
\hline $\mathrm{Sr}$ & -0.7936 & -0.6761 & 0.1861 & 0.5303 & 0.6482 & -0.7859 & -0.7616 & -0.5937 & -0.6070 \\
\hline $\mathrm{Ta}$ & 0.9636 & 0.4143 & -0.7827 & 0.1020 & -0.7567 & 0.9269 & 0.7338 & 0.7698 & 0.8166 \\
\hline Th & -0.1508 & -0.7180 & -0.6006 & 0.9756 & -0.0224 & -0.1736 & -0.4434 & 0.1487 & 0.1118 \\
\hline $\mathrm{Ti}$ & 0.8685 & 0.1581 & -0.8751 & 0.3399 & -0.7930 & 0.8275 & 0.5445 & 0.8169 & 0.8605 \\
\hline V & -0.7908 & -0.3102 & 0.8760 & -0.3295 & 0.3959 & -0.7678 & -0.6451 & -0.5563 & -0.6161 \\
\hline W & 0.9155 & 0.2631 & -0.8241 & 0.2135 & -0.7847 & 0.8774 & 0.6260 & 0.8311 & 0.8875 \\
\hline $\mathrm{Y}$ & -0.8823 & -0.7275 & 0.3110 & 0.4600 & 0.5839 & -0.8518 & -0.8419 & -0.5803 & -0.6737 \\
\hline $\mathrm{Yb}$ & -0.8354 & -0.8647 & 0.1817 & 0.6264 & 0.4864 & -0.8381 & -0.9148 & -0.4778 & -0.5081 \\
\hline
\end{tabular}

and are shown in Fig. 19. The theoretical removal of the trace elements is listed in Table 14. The value for Ta in the raw coal was obtained as a weighted mean value of Ta in the different density products.

The washability curves of $\mathrm{As}$ and $\mathrm{Hg}$ are similar, which is also the case for Ga and W, Mn, Ta and Ti. High removal rates were obtained for these elements during coal preparation because sharp washability curves were obtained. The elements with flat washability curves are evenly distributed in the organic matter and in the minerals and they cannot be effectively removed during coal preparation.

The ash and sulfur content of the clean coal were $9.18 \%$ and $0.43 \%$, respectively, and poor washability was obtained for No. 6 coal. The recovery of trace elements is closely related to their washability, as shown in Table 14. Only Hg, Mn, W, Ta, As, Ti, Ga, Mo have high washability. The relationship between organic affinity and the theoretical removal rate of trace elements in No. 6 coal from Heidaigou mine are shown in Fig. 20. The theoretical removal rates of the trace elements decrease as the organic affinity increases. Most trace elements are closely related to the organic matter in No. 6 coal from Heidaigou mine. This is also shown by the correlation analyses and the theoretical concentration calculations of the trace elements in the maceral groups and in the minerals. Therefore, it is difficult to remove these trace elements during coal preparation.

\section{Conclusions}

Optical microscopy and SEM were used to study the characteristics of minerals and the concentrations of 33 trace elements in No. 6 coal from Heidaigou mine. The distribution of trace elements in the macerals and in the minerals as well as the organic affinity and removability of the trace elements are also discussed.

1. A high mineral content dominated by kaolinite clay minerals was found in No. 6 coal from Heidaigou mine. Bauxite was mainly present as individual particles in the fusinite lumens or was intimately intergrown with carbonate minerals. Its content was relatively high while that of pyrite and quartz was low. Some marcasite with a parallel twin structure, as observed by cross-polarized reflected light, was also 


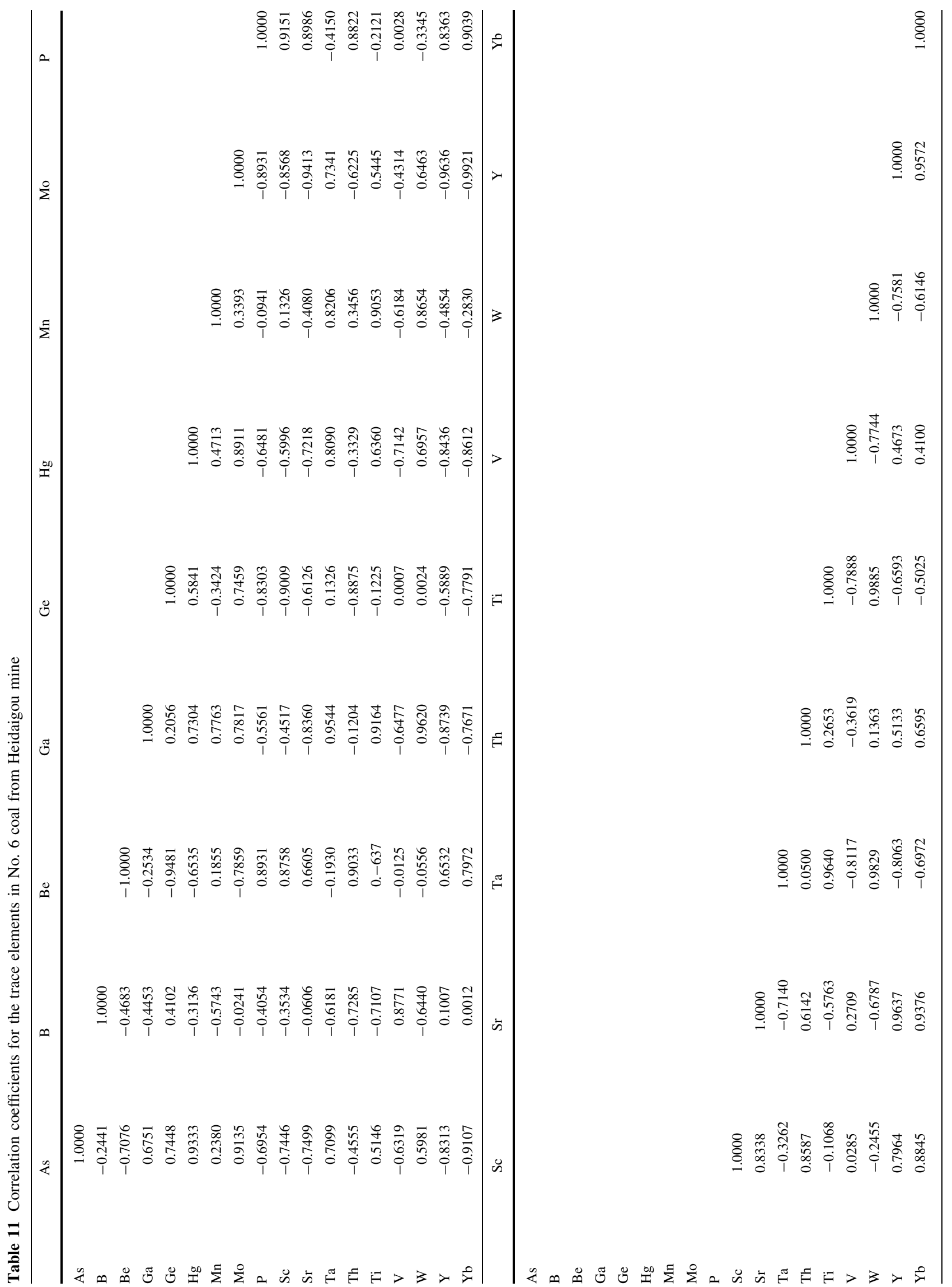


Table 12 Theoretical trace element content in the maceral groups and in the minerals of No. 6 coal from Heidaigou mine, calculated values (in $\mu \mathrm{g} / \mathrm{g})$

\begin{tabular}{|c|c|c|c|c|c|c|c|c|}
\hline \multirow[t]{2}{*}{ Element } & \multicolumn{3}{|c|}{ Component } & \multirow[t]{2}{*}{ Sample amount } & \multicolumn{4}{|c|}{ Significance testing } \\
\hline & Vitrinite & Inertinite & Minerals & & $\mathrm{R}$ & $\mathrm{F}$ & $\mathrm{F}_{0.05}(3, n-4)$ & Significance \\
\hline As & 1.82 & -3.01 & 7.01 & 8 & 0.93 & 10.73 & 6.59 & Significant \\
\hline B & 54.45 & 16.34 & 29.29 & 8 & 0.94 & 12.61 & 6.59 & Significant \\
\hline $\mathrm{Be}$ & 0.69 & 3.19 & 0.52 & 8 & 0.96 & 18.23 & 6.59 & Significant \\
\hline $\mathrm{Ga}$ & 14.37 & 12.8 & 31.83 & 8 & 0.94 & 12.42 & 6.59 & Significant \\
\hline $\mathrm{Ge}$ & 0.04 & 0.04 & 0.04 & 8 & 0.97 & 24.12 & 6.59 & Significant \\
\hline $\mathrm{Hg}$ & 0.128 & 0.114 & 0.413 & 7 & 0.32 & 0.15 & 9.28 & Non-significant \\
\hline $\mathrm{Mn}$ & 11.58 & 2.78 & 109.33 & 7 & 0.89 & 5.09 & 9.28 & Non-significant \\
\hline Mo & 1.47 & 0.28 & 2.35 & 8 & 0.99 & 72.63 & 6.59 & Significant \\
\hline $\mathrm{P}$ & 105.8 & 460.94 & 20.28 & 8 & 0.56 & 0.77 & 6.59 & Non-significant \\
\hline $\mathrm{Sc}$ & 1.23 & 9.63 & -0.56 & 8 & 0.96 & 22.45 & 6.59 & Significant \\
\hline $\mathrm{Sr}$ & 138.63 & 388.46 & -48.11 & 8 & 0.94 & 12.29 & 6.59 & Significant \\
\hline $\mathrm{Ta}$ & 0.27 & 0.66 & 3.04 & 8 & 0.97 & 24.06 & 6.59 & Significant \\
\hline Th & 1.17 & 32.64 & 4.01 & 8 & 0.99 & 82.17 & 6.59 & Significant \\
\hline $\mathrm{Ti}$ & $1,082.59$ & $2,404.66$ & $3,738.02$ & 8 & 0.96 & 17.89 & 6.59 & Significant \\
\hline V & 46.93 & 27.65 & 16.46 & 8 & 0.88 & 5.86 & 6.59 & Significant \\
\hline W & 0.03 & 0.81 & 2.71 & 8 & 0.96 & 17.64 & 6.59 & Significant \\
\hline Y & 11.43 & 24.04 & -1.27 & 8 & 0.95 & 15.28 & 6.59 & Significant \\
\hline $\mathrm{Yb}$ & 1.26 & 3.03 & 0.06 & 8 & 0.99 & 137.42 & 6.59 & Significant \\
\hline
\end{tabular}

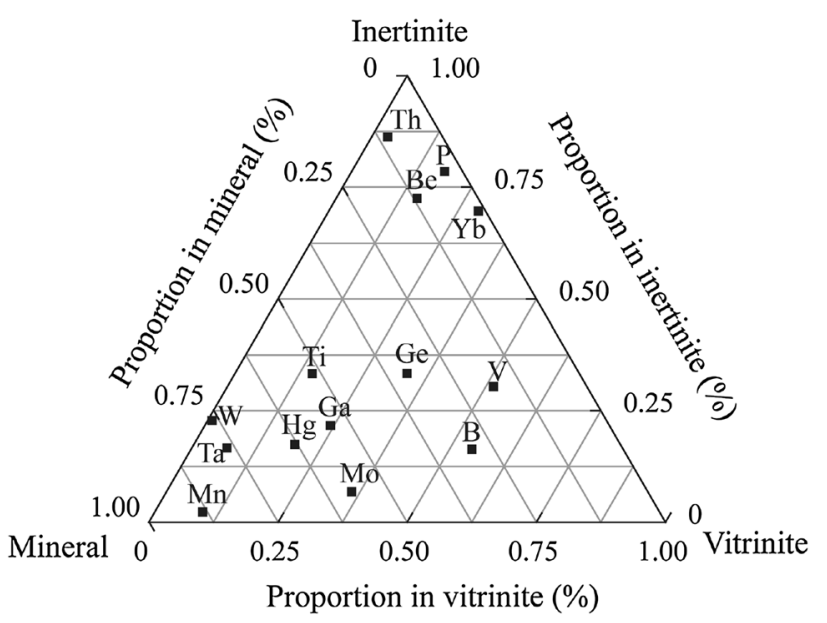

Fig. 18 Ternary diagram showing the distribution of trace elements in No.6 coal

found. A small proportion of bean-like goyazite was found in the calcite.

2. The weighted content of trace elements in Heidaigou formations is relatively low, which is beneficial for
Table 13 Organic affinity of the trace elements in No. 6 coal from Heidaigou mine

\begin{tabular}{lllllllllllll}
\hline Element & As & B & & Be & Ga & Ge & Hg & Mn & Mo & P \\
\hline$A_{\mathrm{o}}$ & 26.66 & 77.75 & 92.11 & 56.05 & - & - & - & 51.61 & - \\
\hline Element & $\mathrm{Sc}$ & $\mathrm{Sr}$ & $\mathrm{Ta}$ & $\mathrm{Th}$ & $\mathrm{Ti}$ & $\mathrm{V}$ & $\mathrm{W}$ & $\mathrm{Y}$ & $\mathrm{Yb}$ \\
\hline$A_{\mathrm{o}}$ & 100 & 100 & 32.05 & 93.07 & 58.93 & 86.98 & 33.05 & 100 & 99.10
\end{tabular}

coal processing and utilization. The concentrations of $\mathrm{Ga}, \mathrm{Hg}, \mathrm{Pb}, \mathrm{Se}, \mathrm{Th}, \mathrm{Ta}$ are relatively high compared to the average values of Chinese coals.

3. As, Hg, Mo, Ge, Ga, Ta, Ti, W, Mn are mainly concentrated in the minerals while $\mathrm{B}, \mathrm{Be}, \mathrm{Th}, \mathrm{P}, \mathrm{Sc}, \mathrm{Sr}$, $\mathrm{V}, \mathrm{Y}, \mathrm{Yb}$ are mainly found in the organic matter in No. 6 coal from Heidaigou mine. As, $\mathrm{Ge}, \mathrm{Hg}$, Mo are mainly present in sulfides, $\mathrm{Be}, \mathrm{Th}, \mathrm{P}, \mathrm{Sc}, \mathrm{Sr}, \mathrm{Y}, \mathrm{Yb}$ are mainly present in inertinite while $\mathrm{B}$ and $\mathrm{V}$ are mainly present in vitrinite. 

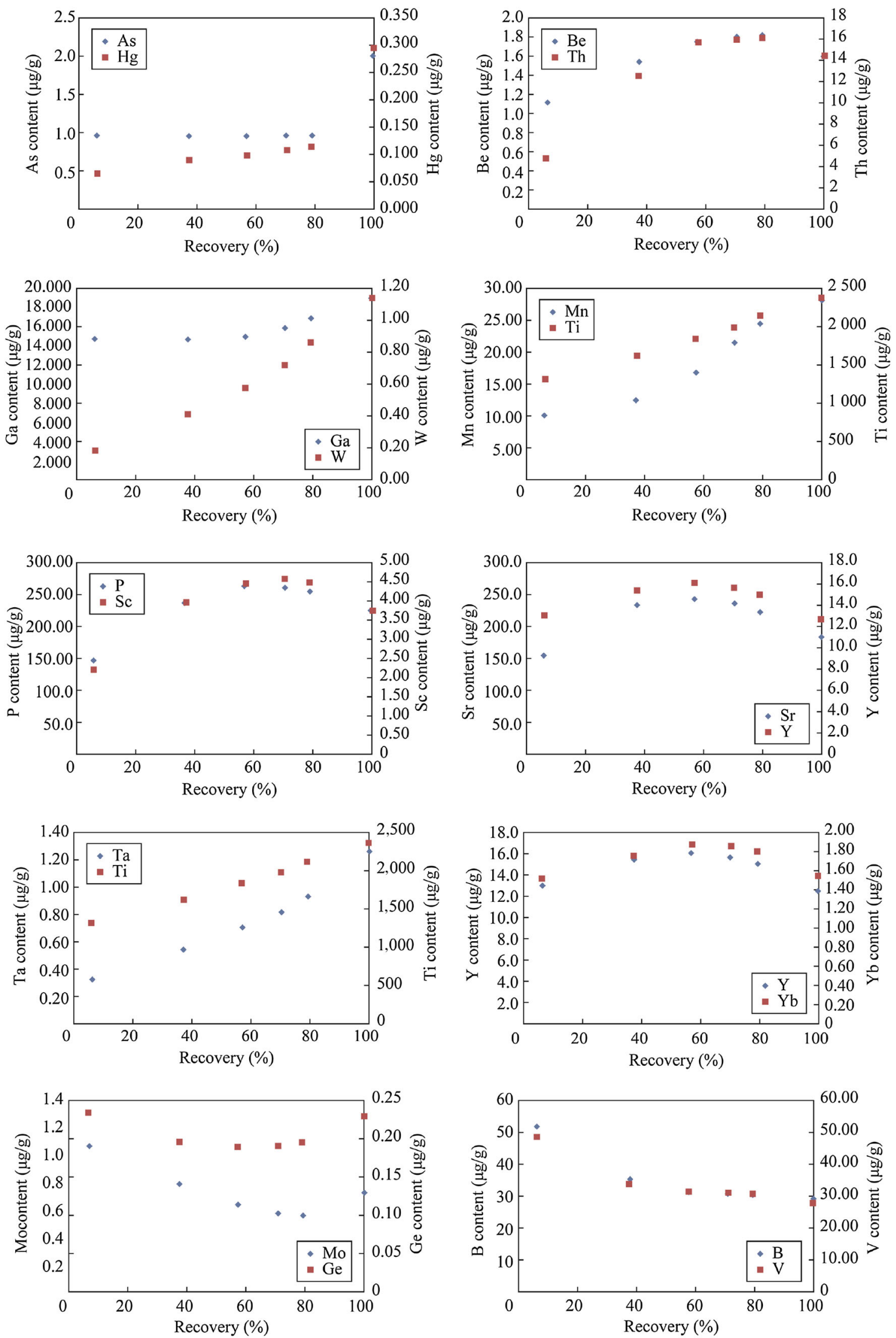

Fig. 19 Washability curves for the trace elements in No. 6 coal from Heidaigou mine 
Table 14 Theoretical removal of trace elements in No. 6 coal from Heidaigou mine (Recovery of clean coal was $57.23 \%$ at a separation density of $1.50 \mathrm{~kg} / \mathrm{L}$ )

\begin{tabular}{llllllllll}
\hline Element & $\mathrm{As}$ & $\mathrm{B}$ & $\mathrm{Be}$ & $\mathrm{Ga}$ & $\mathrm{Ge}$ & $\mathrm{Hg}$ & $\mathrm{Mn}$ & $\mathrm{Mo}$ & $\mathrm{P}$ \\
\hline Theoretical removal rate (\%) & 59.29 & 44.60 & 34.28 & 55.16 & 28.64 & 86.70 & 76.57 & 53.92 & 31.51 \\
\hline Element & $\mathrm{Sc}$ & $\mathrm{Sr}$ & $\mathrm{Ta}$ & $\mathrm{Th}$ & $\mathrm{Ti}$ & $\mathrm{V}$ & $\mathrm{W}$ & $\mathrm{Y}$ & $\mathrm{Yb}$ \\
\hline Theoretical removal rate (\%) & 34.87 & 22.39 & 71.55 & 41.71 & 58.07 & 34.45 & 74.05 & 14.10 & 32.72 \\
\hline
\end{tabular}

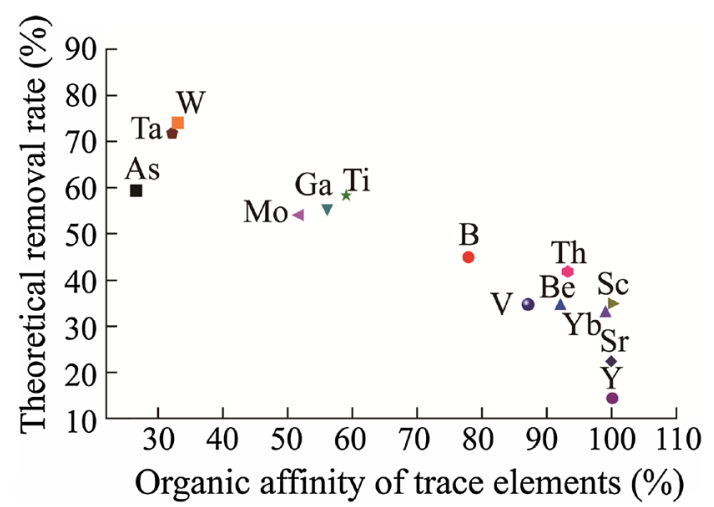

Fig. 20 Relationship between organic affinity and theoretical trace element removal rate in No. 6 coal from Heidaigou mine

4. The high organic affinity and low theoretical removability of most trace elements causes difficulties in their removal during coal preparation.

Acknowledgements Our research was funded by the National Key Basic Research Development Plan (Grant Agreement number 2014CB744302).

Open Access This article is distributed under the terms of the Creative Commons Attribution License which permits any use, distribution, and reproduction in any medium, provided the original author(s) and the source are credited.

\section{References}

Bai XF, Li WH, Chen YF, Jiang Y (2007) The general distributions of trace elements in Chinese coals. Coal Qual Technol 1:1-4

Dai SF, Ren DY, Li SS, Chou CL (2006a) A discovery of extremelyenriched Boehmite from coal in the Junger coalfield, the Northeastern Ordos Basin. Acta Geol Sin 80(2):294-300

Dai SF, Ren DY, Li SS (2006b) Discovery of ultra-large gallium deposit in the Junger Coalfield Inner Mongolia. Chin Sci Bull 51(2):177-185

Dai SF, Ren DY, Chou CL, Li SS, Jiang YF (2006c) Mineralogy and geochemistry of the No. 6 Coal (Pennsylvanian) in the Junger Coalfield, Ordos Basin, China. Int J Coal Geol 66:253-270

Dai SF, Ren DY, Li SS, Zhao L, Zhang Y (2007) Succession characteristics of coal facies of the main coal seam in Heidaigou mine from the Jungar Coalfield, Inner Mongolia. China Earth Sci D 37(supp.):119-126
Dai SF, Li D, Chou CL, Zhao L, Zhang Y, Ren DY, Ma YW, Sun YY (2008) Mineralogy and geochemistry of boehmite-rich coals: new insights from the Haerwusu Surface Mine, Jungar Coalfield, Inner Mongolia, China. Int J Coal Geol 74:185-202

Dai SF, Ren DY, Chou CL, Finkelman RB, Seredin VV, Zhou YP (2012) Geochemistry of trace elements in Chinese coals: a review of abundances, genetic types, impacts on human health, and industrial utilization. Int J Coal Geol 94:3-21

Han DX (editor in chief) (1996). Coal petrology of China. China University of Mining and Technology Press, Xuzhou

Ketris MP, Yudovich YE (2009) Estimations of Clarkes for carbonaceous biolithes: world averages for trace element contents in black shales and coals. Int J Coal Geol 78:135-148

Klika Z, Kolonaznik I (2000) New concept for the calculation of the trace element affinity in coal. Fuel 79:659-670

Klika Z, Weiss Z, Roubicek V (1997) Calculation of element distributions between inorganic and organic parts of coal. Fuel 76(14/15):1537-1544

Li SS, Ren DY (2006) Analysis of anomalous high concentration of lead and selenium and their origin in the main minable coal seam in the Junger Coalfield. J China Univ Min Technol 35(5): $612-616$

Mao JH, Xu HL (1999) Prediction and evaluation of coal resources in China. Science Press, Beijing

Martinez-Tarazona MR, Spears DA, Tascon JMD (1992) Organic affinity of trace elements in Asturian bituminous coals. Fuel 71:909-917

Pires M, Fiedler H, Teixeira EC (1997) Geochemical distribution of trace elements in coal: modeling and environmental aspects. Fuel 76(14/15):1425-1437

Querol X, Klika Z, Weiss Z, Finkelman RB, Alastueya A, Juana R, López-Solera A, Plana F, Kolker A, Chenery SRN (2001) Determination of element affinities by density fractionation of bulk coal samples. Fuel 80:83-96

Reed GP, Ergüdenler A, Grace JR, Watkinson AP, Herod AA, Dugwell D, Kandiyoti R (2001) Control of gasifier mercury emissions in a hot gas filter: the effect of temperature. Fuel 80(5):623-634

Ren DY, Zhao FH, Wang YQ, Yang SJ (1999) Distributions of minor and trace elements in Chinese coals. Int J Coal Geol 40:109-118

Song DY, Zhang XK, Zhang JY, Zheng CG (2010) Migration characteristics of hazardous trace elements in coal in the process of flotation. J China Coal Soc 35(7):1170-1176

Tang YG, Chang CX, Zhang YZ (2005) Migration and distribution of fifteen toxic trace elements during the coal washing of the Kailuan Coalfield Hebei Province. Geochimica 34(4):366-372

Wang WF, Qin Y, Liu XH, Zhao JL, Wang JY, Wu DG, Liu JT (2011) Distribution, occurrence and enrichment causes of gallium in coals from the Jungar Coalfield Inner Mongolia. Sci China Earth Sci 41(2):181-196 